\title{
Article \\ Cultivation Systems, Light Intensity, and Their Influence on Yield and Fruit Quality Parameters of Tomatoes
}

\author{
Larissa Kanski ${ }^{1}$, Hannah Kahle ${ }^{2}$, Marcel Naumann ${ }^{1, *} \mathbb{C}$, Julia Hagenguth ${ }^{3}$, Andreas Ulbrich ${ }^{2}$ \\ and Elke Pawelzik ${ }^{1}$ (D) \\ 1 Division of Quality of Plant Products, Department of Crop Sciences, Faculty of Agriculture, \\ University of Goettingen, Carl-Sprengel-Weg 1, 37075 Goettingen, Germany; \\ lkanski@uni-goettingen.de (L.K.); epawelz@gwdg.de (E.P.) \\ 2 Division of Vegetable Production and Processing, University of Applied Sciences Osnabrueck, \\ Am Krümpel 31, 49090 Osnabrueck, Germany; hannah.kahle@gmx.de (H.K.); \\ A.Ulbrich@hs-osnabrueck.de (A.U.) \\ 3 Division of Plant Breeding Methodology, Department of Crop Sciences, Faculty of Agriculture, \\ University of Goettingen, Carl-Sprengel-Weg 1, 37075 Goettingen, Germany; \\ julia.hagenguth@agr.uni-goettingen.de \\ * Correspondence: marcel.naumann@agr.uni-goettingen.de; Tel.: +49-5513925565
}

check for updates

Citation: Kanski, L.; Kahle, H.; Naumann, M.; Hagenguth, J.; Ulbrich, A.; Pawelzik, E. Cultivation Systems, Light Intensity, and Their Influence on Yield and Fruit Quality Parameters of Tomatoes. Agronomy 2021, 11, 1203. https://doi.org/ 10.3390/agronomy11061203

Academic Editor: Byoung Ryong Jeong

Received: 11 May 2021

Accepted: 7 June 2021

Published: 13 June 2021

Publisher's Note: MDPI stays neutral with regard to jurisdictional claims in published maps and institutional affiliations.

Copyright: (c) 2021 by the authors. Licensee MDPI, Basel, Switzerland. This article is an open access article distributed under the terms and conditions of the Creative Commons Attribution (CC BY) license (https:/ / creativecommons.org/licenses/by/ $4.0 /)$.

\begin{abstract}
The yield and fruit quality parameters of tomatoes are influenced by environmental conditions, and cultivation systems play an important role in improving quality, apart from breeding. We examined five breeding lines and one cultivar in five cultivation systems for yield and fruit quality parameters. The cultivation systems include a single-glazed greenhouse with and without supplementary LED interlighting; a double-glazed greenhouse with and without supplementary LED interlighting; and an organic cultivation system on the field with a rainout shelter. Plants and fruits grown in the double glazing system showed significantly lower values for plant height, yield, DM, TSS, fructose, glucose, antioxidant capacity (DPPH, TEAC), TPC, calcium, phosphorus, and manganese content than in the single-glazed greenhouse, which can be explained by the lower light transmittance. However, it could be seen that the additional LED interlighting could lower the negative effect on yield and quality traits due to double glazing.
\end{abstract}

Keywords: glazing; LED interlighting; antioxidant capacity; aroma compounds; metabolite profile; breeding lines; tomato (Solanum lycopersicum L.)

\section{Introduction}

Tomato is one of the world's favorite vegetables, with 182 million tons produced worldwide in 2018 [1]. It is an important nutrient source for the human diet and rich in antioxidants $[2,3]$. Nevertheless, due to breeding for increased shelf life, yield, and disease resistance, tomato producers face consumer complaints about unsatisfactory fruits [4]. Therefore, a lot of research has been carried out in recent years to map quantitative trait loci (QTL) for sensory traits or aroma compounds [5], as well as for agronomical and consumer-related quality traits (e.g., fruits size, color intensity, firmness, and shape) [6]. Furthermore, breeding programs began to focus on improving quality traits and flavor [7]. Factors influencing quality traits during production are light, nutrient supply, temperature, in season and off season production, water availability, and humidity [8,9]. However, different studies have discussed supplemental lighting with light-emitting diodes (LED) as a possibility to maintain plant and fruit quality, while increasing sustainable production in terms of reduced energy consumption [10-12]. In comparison with high-pressure sodium lamps (HPS lamps), LED lamps can be used as intracanopy lighting because of their reduced heat emission [11]. In general, tomatoes contain health-promoting compounds, which mainly include antioxidant properties $[3,13]$. Increased consumer awareness of food with high nutritional value, has also strengthened the focus on the antioxidant capacity of 
fresh fruits and vegetables [2]. Antioxidants are important to protect cells against damage, which is mediated through oxidative stress, and are important for plants and humans [13]. In their review, Max et al. [14] pointed out the quantity of the literature discussing the effects of light, temperature, or humidity on plant physiology or performance, but not in direct relation to the greenhouse covers. To the best of our knowledge, there are no studies available yet that have comprehensively examined the influence of single glazing or double glazing on fruit quality parameters in tomato production. The reduction of light transmission in double glazing can be up to $20 \%$ compared to single glazing, depending on the material [15]. Despite the reduction in solar radiation, double glazing systems could be a possibility to allow economic and energy-saving year-round production in temperate climates such as Germany [15].

The aim of this study was to investigate to what extent different cultivation systems affect the yield and fruit quality parameters of advanced breeding lines. The parameters were examined in five different environments: in a single-glazed greenhouse with and without supplementary LED interlighting; in a double-glazed greenhouse with and without supplementary LED interlighting; and in an organic cultivation system on the field with a rainout shelter. We focused on the impact of the cultivation systems on fructose and glucose content, total acidity, minerals, antioxidant capacity, total phenolic content, and aroma compounds of the breeding lines and the cultivar Lyterno $\mathrm{F}_{1}$. We also investigated the effect of the two glazing systems and additional LED interlighting on the plants and fruits in more detail by examining the metabolite profile of the fruits and performing a sensory analysis.

\section{Materials and Methods}

\subsection{Plant Material}

Five breeding lines of a targeted selection up to the $\mathrm{F}_{5}$ generation, aimed at adapted cultivars with high nutritional value, preferred flavor compounds, as well as yield parameters (Table 1), were cultivated in 2019 in five cultivation systems (Table 2), together with the cultivar Lyterno $F_{1}$ (Rijk Zwaan ${ }^{\circledR}$, De Lier, The Netherlands). The three salad tomato types had been grown and selected at the University of Applied Sciences in Osnabrueck and the two cocktail tomato types had been grown and selected by Culinaris (Saatgut für Lebensmittel, Goettingen, Germany) under organic low-input conditions. Lyterno $\mathrm{F}_{1}$ has been chosen because it is a parental cultivar and widely used in commercial production.

Table 1. Breeding lines and the cultivar used in this study.

\begin{tabular}{cccc}
\hline $\begin{array}{c}\text { Breeding Line/ } \\
\text { Cultivar }\end{array}$ & $\begin{array}{c}\text { Genotype } \\
\text { Number }\end{array}$ & Genotype & Tomato Fruit Type \\
\hline 1 & 45 & Lyterno $\mathrm{F}_{1} \times$ Primabella & salad \\
2 & 157 & Paul Robson $\times$ Sakura $\mathrm{F}_{1}$ & salad \\
3 & 170 & Paul Robson $\times$ Sakura F & salad \\
4 & $781-11$ & Black Cherry $\times$ Sakura $\mathrm{F}_{1}$ & cocktail \\
5 & $791-11$ & Resi $\times$ Bocati $\mathrm{F}_{1}$ & cocktail \\
6 & & Lyterno $\mathrm{F}_{1}$ & salad \\
\hline
\end{tabular}

\subsection{Growth Conditions}

\subsubsection{Conventional Hydroponic Cultivation Systems}

Cultivation in a hydroponic system took place in two greenhouses at the University of Applied Sciences Osnabrueck ( $\left.52^{\circ} 16^{\prime} 47.68^{\prime \prime} \mathrm{N}, 8^{\circ} 2^{\prime} 49.84^{\prime \prime} \mathrm{E}\right)$, which were identical in construction but different in roofing materials-a $4 \mathrm{~mm}$ single-pane float glass versus a double glazing thermal insulation glass. Overall, plants received $53 \%$ of the solar PAR (photosynthetic active radiation) in the single glazing system and $45 \%$ in the double glazing system [16]. This shows the large impact of the greenhouse construction, as the transmissivity of the single-pane glass is about $90 \%$, whereas the double-pane glass transmits only about $75 \%$ of the incoming radiation [16]. Compared to the single glazing, this resulted in 
a reduction in light intensity for the double glazing of $8 \%$. Each greenhouse contained two treatments with either LED interlighting from sunrise to sunset on the level of the maturing fruits or no additional lighting. The LEDs (Hortiled ${ }^{\circledR}$ Inter, Hortilux Schréder, Monster, The Netherlands) emitted $125 \mu \mathrm{mol} \mathrm{m}{ }^{-2} \mathrm{~s}^{-1}$ with $95 \%$ in the red and $5 \%$ in the blue spectrum, with an integrated optic to light the leaves only from above, with a high proportion of diffused light. Plants were sown in week 16 in Seedlingsubstrat (Klasmann-Deilmann, Geeste, Germany) in the greenhouse $\left(22^{\circ} \mathrm{C}\right.$ day $/ 20^{\circ} \mathrm{C}$ night). After two weeks, they were transplanted to rockwool cubes (Grodan ${ }^{\circledR}$, Roermond, The Netherlands) at $20^{\circ} \mathrm{C}$ day and $18^{\circ} \mathrm{C}$ night temperatures. Planting took place in week 24 , with a distance of $0.33 \mathrm{~m}$ within the row (three plants per one substrate slab) and $1.4 \mathrm{~m}$ distance between the rows in a complete randomized block design, with four biological replications and three plants per replication. Temperature and relative humidity were recorded every $10 \mathrm{~min}$ by sensors hanging between the plants in the height of $1.5 \mathrm{~m}$. The vapor pressure deficit (VPD) was calculated according to Shamshiri et al. [9]. To exclude fringe effects, each treatment was bordered with one enclosing row. Plants were fertigated with a nutrient solution for tomato cultivation conventionally used in horticulture in a recirculating system depending on the state of development [17]. The fertilizer concentration was adjusted by the continuous measurement of the electric conductivity in the backflow of the system; it ranged between 1.8 and $3.5 \mathrm{mS} / \mathrm{cm}$. Only beneficial arthropods were used for biological pest control.

Table 2. Characterization of the five cultivation systems (CS).

\begin{tabular}{cl}
\hline CS & Characterization \\
\hline 1 & Single-glazed greenhouse with LED interlighting, conventional hydroponic cultivation system \\
2 & Single-glazed greenhouse without LED interlighting, conventional hydroponic cultivation system \\
3 & Double-glazed greenhouse (low-energy-greenhouse) with LED interlighting, conventional hydroponic cultivation system \\
4 & Double-glazed greenhouse (low-energy-greenhouse) without LED interlighting, conventional hydroponic cultivation system \\
5 & Organic low-input cultivation system on the field with a rainout shelter \\
\hline
\end{tabular}

\subsubsection{Organic Low-Input Cultivation System}

The organic low-input cultivation took place on a field at the experimental station Reinshof, Goettingen ( $\left.51^{\circ} 30^{\prime} 17.6^{\prime \prime} \mathrm{N}, 9^{\circ} 55^{\prime} 16.2^{\prime \prime} \mathrm{E}\right)$ at the University of Goettingen. For the minimization of Phytophthora infestans and Cladosporium fulvum infestation, the plants were sheltered with a rainout shelter. The roofing material was a highly transparent UV stabilized film with a transmission of up to $89 \%$ between $400-700 \mathrm{~nm}$, resulting in a share of about 23\% diffused light (Euro 4, FVG Folien-Vertriebs GmbH, Dernbach, Germany). The plant material was sown in week 16, in Bio-Traysubstrat (Klasmann-Deilmann, Geeste, Germany) in the greenhouse $\left(22{ }^{\circ} \mathrm{C}\right.$ day $/ 18{ }^{\circ} \mathrm{C}$ night). After two weeks, plants were transferred to bigger pots $\left(22^{\circ} \mathrm{C}\right.$ day $/ 15^{\circ} \mathrm{C}$ night). With the end of week 22 , the plants were cultivated on the field in a complete randomized block design, with 4 biological replications (between four to five plants per replication) and $1 \mathrm{~m}$ distances between the rows and $0.5 \mathrm{~m}$ distances within the rows. The plants were bordered with three plants at the end of each row and one edge row on each side. In total, 18 Lyterno $F_{1}$ plants and 17 plants of each $F_{5}$ breeding line were cultivated. No fertilizer was applied during the entire cultivation period. Neudosan Neu (Neudorff ${ }^{\circledR}$, Emmerthal, Germany) was applied twice against mites. The pre-crop in the field was winter wheat. Plants were watered with a dripping system and a total amount of $187 \mathrm{~L} / \mathrm{m}^{2}$.

\subsection{Agronomic and Yield Parameters}

To evaluate the plant performance, plants in all cultivation systems were monitored up to $2.5 \mathrm{~m}$ in plant height. The growth rate was determined by recording the time from planting to $2.5 \mathrm{~m}$ height for every plant. Counting the trusses up to this height allowed the calculation of the number of trusses build by the plant per week. The single fruit weight was determined from truss one to three to calculate the overall yield up to $2.5 \mathrm{~m}$ 
plant height and the average weight of fruits built per week since planting. According to commercial tomato production, trusses were limited to a certain number of fruits to ensure uniform fruit weight per truss. Six fruits for breeding lines/cultivar above $40 \mathrm{~g}$ fruit weight (breeding lines/cultivar 1, 2, 3,6) and ten fruits for breeding lines below $40 \mathrm{~g}$ fruit weight (breeding lines 4 and 5) were allowed per truss.

\subsection{Harvest and Sample Processing}

Harvesting took place in weeks 33 and 34. For each of the four replications, ripe fruits were harvested. Three to six fruits per biological replication were used for analyses. Two biological replications were pooled for the panel evaluation. Color measurements and panel sensory analysis were directly conducted on fresh fruits. For aroma analysis, fruits were processed, and, subsequently, frozen at $-20{ }^{\circ} \mathrm{C}$ until analysis. Some of the fruits were cut and frozen at $-20^{\circ} \mathrm{C}$ until they were used for the measurement of total soluble solids (TSS), titratable acidity (TA), dry matter (DM), and pH analyses. Further sample material was freeze-dried (EPSILON 2-40, Christ, Osterode am Harz, Germany), and, subsequently, ground with a ball mill before being used for mineral, glucose, and fructose extraction, and to determine total phenolic content and antioxidant capacity.

\subsection{Fruit Quality Parameters and Chemical Analyses}

Color measurements were implemented on two to five fruits on opposite equatorial sites for each replication with a Minolta Chroma meter CR-400 (Konica Minolta, Inc., Marunouchi, Japan). For the TSS, TA, and DM content, the frozen material was thawed and analyzed, as described in Kanski et al. [18]. The $\mathrm{pH}$ value was recorded with the $\mathrm{pH}$ titrator (Titroline 96, SCHOTT AG, Mainz, Germany) at the beginning of the titration for the TA. For the concentrations of fructose, glucose, and minerals, methods were applied as previously described [18] with some modifications. A total of $100 \mathrm{mg}$ of freeze-dried material was used for the glucose and fructose extraction. The aroma compounds were extracted and analyzed as well, as described in Kanski et al. [18]. The calculation was done as described in Zhang et al. [19], with 1-octanol as the internal standard. The relative concentration in relation to 1-octanol was expressed in $\mathrm{ng} / \mathrm{mL}$ sample. The aroma compounds were $\log _{2}$-transformed before performing ANOVA analyses.

\subsection{Total Phenolic Content and Antioxidant Capacity}

To measure the total phenolic content and the antioxidant capacity of the fruits, $50 \mathrm{mg}$ of freeze-dried material were weighed in $2 \mathrm{~mL}$ tubes. For the extraction, $1 \mathrm{~mL}$ of methanol (Rotislov ${ }^{\circledR}$, HPLC Gradient Grade, Roth, Germany) was pipetted to the sample, shaken for $15 \mathrm{~min}$ at $600 \mathrm{rpm}$, and, subsequently, centrifuged for $10 \mathrm{~min}$ at 10,000 rpm (Centrifuge 5804 R, Eppendorf, Hamburg, Germany). The supernatant was transferred to a new tube and the extraction was repeated. The two supernatants were combined and filled up to $2 \mathrm{~mL}$ with methanol. This extraction method was used for the total phenolic content (TPC), the Trolox equivalent antioxidant capacity (TEAC), and the 2,2-diphenyl-1picrylhydrazyl (DPPH) radical scavenging assay. The TPC in the fruits were determined with Folin-Ciocalteu reagent and expressed as $\mathrm{mg}$ gallic-acid equivalent per $100 \mathrm{~g}$ fresh weight. The method of Asami et al. (2003) was applied with some modifications. Instead of a photometer, a plate reader (Synergy HTX multi-mode reader, BioTek, Bad Friedrichshall, Germany) was used, the quantities were accordingly adjusted, and $\mathrm{NaOH}$ was used as a buffer instead of $\mathrm{Na}_{2} \mathrm{CO}_{3}$. The absorbance was measured at $736 \mathrm{~nm}$. For the TEAC assay, first, the stock solution was prepared through the reaction of $0.7 \mathrm{mM} \mathrm{ABTS}\left(2,2^{\prime}\right.$-azino-bis (3-ethylbenzothiazoline-6-sulfonic acid)) with $0.25 \mathrm{mM} \mathrm{K}_{2} \mathrm{~S}_{2} \mathrm{O}_{8}$. For the ABTS ${ }^{\bullet+}$ working solution, the stock solution was diluted five times with methanol. A total of $10 \mu \mathrm{L}$ of the extracted sample was mixed with $150 \mu \mathrm{L} \mathrm{ABTS}{ }^{\bullet+}$ working solution and incubated at room temperature for $6 \mathrm{~min}$ with orbital shaking $(425 \mathrm{rpm})$. The absorption was measured at $734 \mathrm{~nm}$ and the results were expressed as Trolox equivalents ( $\mu$ mol TE/100 g FW). All samples and standards were measured in triplicates. For the DPPH radical scavenging 
assay, $20 \mu \mathrm{L}$ sample extract was added to $180 \mu \mathrm{L} 0.2 \mathrm{mM}$ DPPH dissolved in methanol, incubated for $30 \mathrm{~min}$ at room temperature, and the absorption was measured at $515 \mathrm{~nm}$. All measurements were performed in triplicate and expressed as Trolox equivalents ( $\mu$ mol $\mathrm{TE} / 100 \mathrm{~g}$ FW).

\subsection{Sensory Evaluation by a Trained Panel}

The sensory evaluation was conducted in a sensory lab with 10 selected assessors, in accordance with DIN EN ISO 8586 [20] guidelines for their selection. The assessors were trained over nine sessions twice a week, with a total of $16 \mathrm{~h}$ training. The panel leader acted as a consultant, listing a selection of references for the selected attributes, and assisting the panel in reaching a consensus. However, the panel leader did not specify the attributes; rather, the attributes were collected by the panel and selected by consensus. The compiled attributes evaluated by the assessors were overall intensityodor, green/grassy odor, tomato-typical odor, overall intensity-flavor, tomato-typical flavor, fruity flavor, sweetness, sourness, bitterness, saltiness, umami, juiciness, firmness, and aftertaste. Unstructured line scales were used for the evaluation, ranging from not perceptible or weak to strongly perceptible or very strong, depending on the attribute. The data evaluation was performed in four sessions with a randomized sample order. The assessors received at least half a fruit for each evaluation. The samples were evaluated in duplicates and for neutralization tap water, unsalted cracker (P. Heumann's Matzen, Aerzen, Germany), and peeled cucumber pieces were served to clean the palate as well as coffee beans to neutralize the olfactory sense. The sensory test was always carried out the day after harvest. The fruits were stored overnight at room temperature. During the test sessions, assessors sat separated in individual booths in the sensory lab of the University of Goettingen, designed in accordance with DIN EN ISO 8589 [21].

\subsection{Metabolite Profiling}

Metabolite profiling was performed for the breeding lines 2 and 3, and the cultivar Lyterno $F_{1}$, grown in two cultivation systems: the single-glazed greenhouse without additional LED interlighting (CS 2) and the double-glazed greenhouse without additional LED interlighting (CS 4). The analysis and the extraction were conducted at lifespin $\mathrm{GmbH}$, Germany. Fresh material was immediately frozen in liquid nitrogen and stored at $-80{ }^{\circ} \mathrm{C}$ until preparation. Freeze-dried material was milled with a ball mill and an aliquot of $100 \mathrm{mg}$ was weighed and extracted with $1500 \mu \mathrm{L}$ of a phosphate buffer containing $5 \%$ $\mathrm{D}_{2} \mathrm{O}$. The mixture was incubated for $20 \mathrm{~min}$ at $85{ }^{\circ} \mathrm{C}$ and cooled down for $40 \mathrm{~min}$ to room temperature under continuous shaking at $1000 \mathrm{rpm}$. After centrifugation at $20,000 \times g$, the aqueous supernatant was spiked with a $10 \%$ lifespin additive solution (internal standard and NMR-reference for aqueous samples). Subsequently, $600 \mu \mathrm{L}$ of the mixtures were filled in $5 \mathrm{~mm}$ NMR tubes and measured by a nuclear magnetic resonance spectrometer (Bruker AVANCE III HD 600 MHz; method: 1D 1H noesygppr, NS = 32, T = 298 K). All spectra passed lifespin QC-routine and were approved for data analysis. The spectra that were obtained were analyzed using lifespin's proprietary profiling software (V1.2.3, customized for tomato extracts). The metabolites were identified by comparison with lifespin's database and subsequently quantified against TSP (trimethylsilylpropanoic acid) (0.0 ppm, 9 protons). The concentration of each metabolite was expressed as mg per $\mathrm{g}$ dry matter (mg/g DM).

\subsection{Statistical Analyses}

Two- and three-way analysis of variance (ANOVA), followed by Tukey's HSD Test $(p \leq 0.05)$, were conducted to show significant differences. For the metabolite analysis, a $t$-test was conducted to show the influence of the single glazing and double glazing (CS 2 and CS 4). Statistical analyses were performed using SPSS statistical software (IBM statistics Version 25.0, Armond, NY, USA). 


\section{Results}

\subsection{Environmental Conditions in the Cultivation Systems}

Temperature, relative humidity, and vapor pressure deficit were measured over the entire growth period (Figure S1). For the different growth conditions shown in Figure 1, data from planting until the end of fruit harvest in week 34 were summarized. Depending on their effects on plant and fruit development, they were divided into three classes: optimum, below optimum, and above optimum, in accordance with Shamshiri et al. [9]. The cultivation systems were grouped, distinguishing between the single-glazed (CS 1 and CS 2) and the double-glazed (CS 3 and CS 4) greenhouse, and the organic cultivation system (CS 5) (Figure 1 and Figure S1). Temperature and relative humidity values showed that more than $95 \%$ and $97 \%$ of the measurements were in the optimum range in CS 1 to 4 . Meanwhile, in the organic cultivation system (CS 5), only $68.51 \%$ of the temperature values were in the optimum range and $24.96 \%$ were below this range. Furthermore, $24.8 \%$ of the relative humidity values in CS 5 were above the optimum range (Figure 1A,B). Figure 1C shows the distribution of the vapor pressure deficit (VPD). According to Shamshiri et al. [9], groups for VPD were formed to distinguish between the optimum range for plant growth and fruit development $(0.4-1.3 \mathrm{kPa})$ and values that are supposed to be below $(<0.4 \mathrm{kPa}=$ too wet, limited transpiration) or above the optimum $(>1.3 \mathrm{kPa}=$ too dry, heavy transpiration). Corresponding to the temperature and the relative humidity values, the distribution of the VPD values showed that more than $50 \%$ of the values, during the period under investigation, were in the optimum range in the CSs 1 to 4 , while the optimum VPD was achieved only in $23.8 \%$ for CS 5 . Moreover, $41.4 \%$ of the values in the organic cultivation system (CS 5) ranged in the group below $0.4 \mathrm{kPa}$. Meanwhile, the values higher than $1.3 \mathrm{kPa}$ ranged from $32 \%$ to $34.9 \%$ between the CSs. Hence, it can be summarized that, in comparison with CSs 1 to 4, for the organic cultivation system (CS 5), periods outside the optimum occurred in a VPD lower than $0.4 \mathrm{kPa}$. Depending on the covering material and the construction, light intensity differed among the cultivation systems. Long term measurements showed an amount of PAR on plant level of 53\% in CS 1 and 2 and of $45 \%$ in CS 3 and 4. For CS 5, it can be assumed that light intensity was higher than in CS 1 to 4 , due to a plastic cover and the light construction with little shading. Covering of CS 1 to 4 showed only marginal effects in temperature and relative humidity, due to precise climate control (Figure S1).

\subsection{Comparison of Yield, Fruit Quality Attributes, Antioxidant Capacity, and Mineral Content}

Fruits from the organic cultivation system (CS 5) and the single-glazed greenhouse with supplementary LED lighting (CS 1) resulted in the highest fruit weights (Table S1). However, as plants in CS 5 required about 4.4 weeks longer to reach the height of $2.5 \mathrm{~m}$, it can be estimated that fruit harvest was also delayed in comparison with CS 1 (Table S1). The TSS content of the fruits only differed significantly between the greenhouse with single glazing without LED (CS 2), and double glazing without LED (CS 4), while the TA fruit content from the organic cultivation system (CS 5) was significantly lower (Table 3). Glucose content showed a similar pattern, such as the TSS value, with fruits from CS 2 showing the highest concentrations and CS 4 the lowest (Table 3). However, glucose content was significantly different between fruits from the single-glazed greenhouse without LED interlighting (CS 2) and the double-glazed greenhouse, whether with or without additional interlighting (CS 3-4). Fructose content was significantly lower in fruits from the doubleglazed greenhouse with no supplementary interlighting (CS 4) compared to fruits from the organic cultivation system (CS 5) and the single-glazed greenhouses (CS 1 and 2) (Table 3). The antioxidant capacity measured within the TEAC and DPPH assay showed the lowest values in fruits from CS 4 (Table 3), corresponding to the concentration of total phenolics, which also showed the significant lowest concentration in fruits from CS 4 (Table 3). Furthermore, the antioxidant capacity was significantly different between fruits from the double-glazed cultivation system without additional interlighting (CS 4) and both single-glazed greenhouse environments (CS 1 and 2) (Table 3). Mineral content in 
the fruits differ significantly between the organic cultivation system (CS 5) and the four conventional hydroponic systems (CS 1-4) (Table 4). Thereby, the contents were significantly lower in fruits from CS 5, except for calcium, which was found in a significantly higher concentration in these fruits compared to fruits grown in the hydroponic systems (CS 1-4) (Table 4). In contrast, other immobile nutrients like iron and manganese did not show a significant increase in CS 5 (Table 4). The soil analyses from CS 5 showed that the amounts of potassium, phosphorus, and magnesium were at either the targeted level (C) or even highly available (level D) in the soil (Table S2). The relative concentration of 18 different showed no clear pattern in the fruits for one cultivation system (Table S3). The relative concentrations of 6-methyl-5-hepten-2-one, phenylacetaldehyde, methyl salicylate, and $ß$-damascenone in the fruits were not significantly different between all CSs. The fruits from the breeding lines/cultivar showed significant differences for all quality parameters, except for the relative concentrations of geranial (Table 3, Table 4 and S3). The smaller fruit types contained higher fructose concentrations than the larger fruited breeding lines, and the lowest fructose contents were found in fruits from the cultivar Lyterno $F_{1}$ (Table 3).
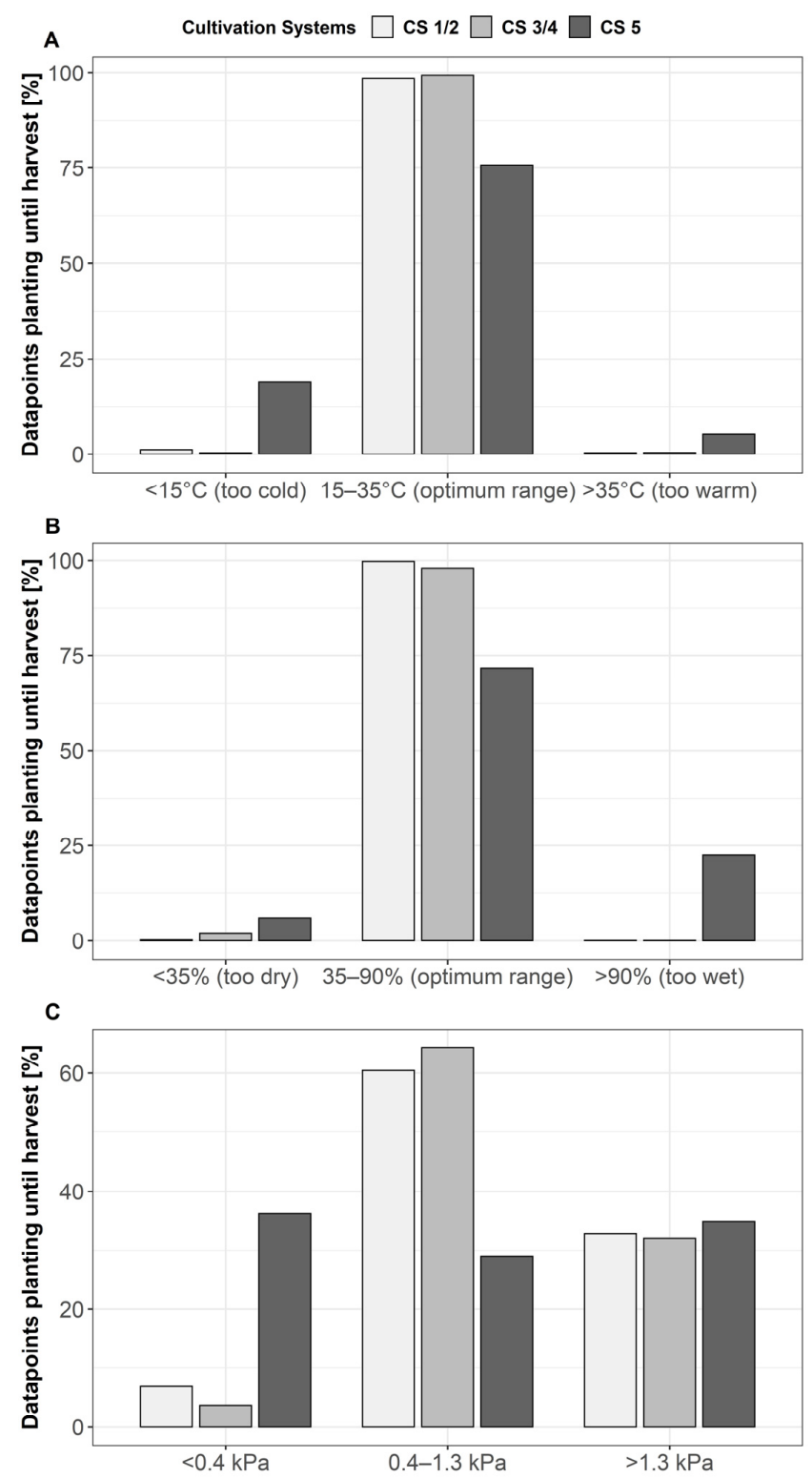

Figure 1. Distribution of (A) temperature values, $(\mathbf{B})$ relative humidity values, and $(\mathbf{C})$ vapor pressure deficit (VPD) values in percentage, from planting until harvest. 


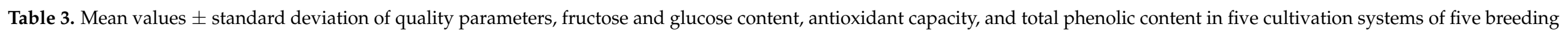
lines and Lyterno $F_{1}$, calculated on fresh matter basis.

\begin{tabular}{|c|c|c|c|c|c|c|c|c|c|c|c|c|c|c|}
\hline & \multicolumn{6}{|c|}{ Cultivation System (CS) } & \multicolumn{7}{|c|}{ Breeding Line $(\mathrm{BL}) / \mathrm{Cultivar}(\mathrm{CV})$} & \multirow[t]{2}{*}{$\begin{array}{r}\mathrm{BL} / \mathrm{CV} \\
\times \mathrm{CS}\end{array}$} \\
\hline & 1 & 2 & 3 & 4 & 5 & & 1 & 2 & 3 & 4 & 5 & 6 & & \\
\hline Dry matter [\%] & $\begin{array}{l}7.33 \pm \\
1.07 \mathrm{a}\end{array}$ & $\begin{array}{c}7.22 \pm \\
1.39 \mathrm{a}\end{array}$ & $\begin{array}{l}6.88 \pm \\
1.01 \mathrm{ab}\end{array}$ & $\begin{array}{l}6.58 \pm \\
1.34 \mathrm{~b}\end{array}$ & $\begin{array}{l}6.97 \pm \\
0.86 \mathrm{ab}\end{array}$ & $* * *$ & $\begin{array}{l}6.5 \pm \\
0.68 b\end{array}$ & $\begin{array}{c}7.68 \pm \\
0.83 \mathrm{a}\end{array}$ & $\begin{array}{c}6.1 \pm \\
0.45 \mathrm{bc}\end{array}$ & $\begin{array}{c}7.86 \pm \\
0.67 \mathrm{a}\end{array}$ & $\begin{array}{c}8.14 \pm \\
0.77 \mathrm{a}\end{array}$ & $\begin{array}{r}5.67 \pm \\
0.61 \mathrm{c}\end{array}$ & $* * *$ & $* *$ \\
\hline TSS $\left[{ }^{\circ}\right.$ Brix $]$ & $\begin{array}{l}6.56 \pm \\
1.10 \mathrm{ab}\end{array}$ & $\begin{array}{l}6.78 \pm \\
1.18 \mathrm{a}\end{array}$ & $\begin{array}{c}6.19 \pm \\
0.89 \mathrm{ab}\end{array}$ & $\begin{array}{l}6.15 \pm \\
1.16 \mathrm{~b}\end{array}$ & $\begin{array}{l}6.33 \pm \\
0.97 \mathrm{ab}\end{array}$ & $* *$ & $\begin{array}{l}5.75 \pm \\
0.79 \mathrm{~b}\end{array}$ & $\begin{array}{c}6.93 \pm \\
0.85 \mathrm{a}\end{array}$ & $\begin{array}{l}5.8 \pm \\
0.87 \mathrm{~b}\end{array}$ & $\begin{array}{c}7.45 \pm \\
0.42 \mathrm{a}\end{array}$ & $\begin{array}{c}6.99 \pm \\
0.80 \mathrm{a}\end{array}$ & $\begin{array}{c}5.47 \pm \\
0.84 \mathrm{~b}\end{array}$ & $* * *$ & ns \\
\hline TA [\%] & $\begin{array}{c}0.58 \pm \\
0.14 \mathrm{a}\end{array}$ & $\begin{array}{c}0.58 \pm \\
0.16 \mathrm{a}\end{array}$ & $\begin{array}{c}0.56 \pm \\
0.13 \mathrm{a}\end{array}$ & $\begin{array}{c}0.57 \pm \\
0.15 \mathrm{a}\end{array}$ & $\begin{array}{c}0.47 \pm \\
0.09 \mathrm{~b}\end{array}$ & $* * *$ & $\begin{array}{r}0.43 \pm \\
0.13 c\end{array}$ & $\begin{array}{l}0.51 \pm \\
0.07 \mathrm{bc}\end{array}$ & $\begin{array}{l}0.48 \pm \\
0.07 \mathrm{bc}\end{array}$ & $\begin{array}{c}0.67 \pm \\
0.11 \mathrm{a}\end{array}$ & $\begin{array}{c}0.71 \pm \\
0.12 \mathrm{a}\end{array}$ & $\begin{array}{c}0.52 \pm \\
0.09 \mathrm{~b}\end{array}$ & $* * *$ & ns \\
\hline $\mathrm{pH}$ & $\begin{array}{c}4.2 \pm \\
0.14 \mathrm{ab}\end{array}$ & $\begin{array}{c}4.27 \pm \\
0.18 \mathrm{a}\end{array}$ & $\begin{array}{l}4.22 \pm \\
0.13 \mathrm{ab}\end{array}$ & $\begin{array}{l}4.21 \pm \\
0.16 \mathrm{ab}\end{array}$ & $\begin{array}{l}4.14 \pm \\
0.08 \mathrm{~b}\end{array}$ & $* *$ & $\begin{array}{l}4.22 \pm \\
0.10 \mathrm{bc}\end{array}$ & $\begin{array}{l}4.26 \pm \\
0.11 \mathrm{~b}\end{array}$ & $\begin{array}{c}4.36 \pm \\
0.14 \mathrm{a}\end{array}$ & $\begin{array}{l}4.14 \pm \\
0.07 \mathrm{c}\end{array}$ & $\begin{array}{l}4.14 \pm \\
0.12 \mathrm{c}\end{array}$ & $\begin{array}{l}4.13 \pm \\
0.16 \mathrm{c}\end{array}$ & $* * *$ & ns \\
\hline$a^{*}$ value & $\begin{array}{c}14.03 \pm \\
4.29 \mathrm{~b}\end{array}$ & $\begin{array}{c}13.92 \pm \\
4.71 \mathrm{~b}\end{array}$ & $\begin{array}{c}14.01 \pm \\
4.48 \mathrm{~b}\end{array}$ & $\begin{array}{c}13.59 \pm \\
4.26 \mathrm{~b}\end{array}$ & $\begin{array}{c}15.23 \pm \\
4.17 \mathrm{a}\end{array}$ & $* *$ & $\begin{array}{c}18.01 \pm \\
1.58 \mathrm{a}\end{array}$ & $\begin{array}{c}14.54 \pm \\
1.87 \mathrm{~b}\end{array}$ & $\begin{array}{c}10.54 \pm \\
2.17 \mathrm{c}\end{array}$ & $\begin{array}{l}7.4 \pm \\
0.89 \mathrm{~d}\end{array}$ & $\begin{array}{c}18.75 \pm \\
1.54 \mathrm{a}\end{array}$ & $\begin{array}{l}15.7 \pm \\
1.46 \mathrm{~b}\end{array}$ & $* * *$ & $* * *$ \\
\hline Hue angle $\left[{ }^{\circ}\right]$ & $\begin{array}{l}62.09 \pm \\
4.64 \mathrm{ab}\end{array}$ & $\begin{array}{c}61.78 \pm \\
5.72 \mathrm{ab}\end{array}$ & $\begin{array}{c}62.37 \pm \\
5.06 \mathrm{a}\end{array}$ & $\begin{array}{c}62.52 \pm \\
5.17 \mathrm{a}\end{array}$ & $\begin{array}{c}60.73 \pm \\
3.80 \mathrm{~b}\end{array}$ & * & $\begin{array}{c}58.09 \pm \\
2.19 \mathrm{c}\end{array}$ & $\begin{array}{c}61.62 \pm \\
2.89 \mathrm{~b}\end{array}$ & $\begin{array}{c}67.07 \pm \\
3.45 \mathrm{a}\end{array}$ & $\begin{array}{c}67.59 \pm \\
1.81 \mathrm{a}\end{array}$ & $\begin{array}{c}56.52 \pm \\
2.42 \mathrm{c}\end{array}$ & $\begin{array}{l}60.5 \pm \\
2.20 \mathrm{~b}\end{array}$ & $* * *$ & $* * *$ \\
\hline Fructose $[\mathrm{g} / 100 \mathrm{~g}]$ & $\begin{array}{l}1.89 \pm \\
0.36 \mathrm{ab}\end{array}$ & $\begin{array}{c}1.98 \pm \\
0.42 \mathrm{a}\end{array}$ & $\begin{array}{l}1.85 \pm \\
0.28 \mathrm{ab}\end{array}$ & $\begin{array}{l}1.76 \pm \\
0.42 \mathrm{~b}\end{array}$ & $\begin{array}{c}1.98 \pm \\
0.44 \mathrm{a}\end{array}$ & $* * *$ & $\begin{array}{r}1.78 \pm \\
0.21 \mathrm{c}\end{array}$ & $\begin{array}{c}2.07 \pm \\
0.32 \mathrm{~b}\end{array}$ & $\begin{array}{l}1.58 \pm \\
0.14 \mathrm{~d}\end{array}$ & $\begin{array}{c}2.26 \pm \\
0.21 \mathrm{a}\end{array}$ & $\begin{array}{c}2.24 \pm \\
0.19 \mathrm{a}\end{array}$ & $\begin{array}{c}1.42 \pm \\
0.18 \mathrm{e}\end{array}$ & $* * *$ & $* * *$ \\
\hline Glucose $[\mathrm{g} / 100 \mathrm{~g}]$ & $\begin{array}{c}1.7 \pm \\
0.35 \mathrm{ab}\end{array}$ & $\begin{array}{l}1.8 \pm \\
0.42 \mathrm{a}\end{array}$ & $\begin{array}{l}1.63 \pm \\
0.25 \mathrm{~b}\end{array}$ & $\begin{array}{l}1.58 \pm \\
0.40 \mathrm{~b}\end{array}$ & $\begin{array}{c}1.7 \pm \\
0.37 \mathrm{ab}\end{array}$ & $* * *$ & $\begin{array}{l}1.51 \pm \\
0.21 \mathrm{~b}\end{array}$ & $\begin{array}{c}1.91 \pm \\
0.30 \mathrm{a}\end{array}$ & $\begin{array}{l}1.39 \pm \\
0.11 \mathrm{bc}\end{array}$ & $\begin{array}{c}2.04 \pm \\
0.18 \mathrm{a}\end{array}$ & $\begin{array}{c}1.98 \pm \\
0.17 \mathrm{a}\end{array}$ & $\begin{array}{c}1.26 \pm \\
0.19 c\end{array}$ & $* * *$ & $* *$ \\
\hline DPPH $[\mu \mathrm{mol} / 100 \mathrm{~g}]$ & $\begin{array}{l}138.45 \pm \\
28.45 a b\end{array}$ & $\begin{array}{c}140.19 \pm \\
28.54 \mathrm{a}\end{array}$ & $\begin{array}{l}123.91 \pm \\
21.61 \mathrm{bc}\end{array}$ & $\begin{array}{c}119.82 \pm \\
27.90 c\end{array}$ & $\begin{array}{l}124.55 \pm \\
24.07 \mathrm{bc}\end{array}$ & $* * *$ & $\begin{array}{l}134.22 \pm \\
17.68 \mathrm{bc}\end{array}$ & $\begin{array}{c}128.31 \pm \\
24.73 c\end{array}$ & $\begin{array}{c}109.16 \pm \\
12.75 \mathrm{~d}\end{array}$ & $\begin{array}{c}152.28 \pm \\
18.96 \mathrm{a}\end{array}$ & $\begin{array}{l}151.59 \pm \\
21.01 \mathrm{ab}\end{array}$ & $\begin{array}{c}101.47 \pm \\
18.59 \mathrm{~d}\end{array}$ & $* * *$ & ns \\
\hline TEAC $[\mu \mathrm{mol} / \mathbf{1 0 0} \mathrm{g}]$ & $\begin{array}{l}164.46 \pm \\
29.95 \mathrm{ab}\end{array}$ & $\begin{array}{c}174.33 \pm \\
33.50 \mathrm{a}\end{array}$ & $\begin{array}{l}157.22 \pm \\
25.35 \mathrm{bc}\end{array}$ & $\begin{array}{c}149.19 \pm \\
29.13 c\end{array}$ & $\begin{array}{l}152.53 \pm \\
25.53 \mathrm{bc}\end{array}$ & $* * *$ & $\begin{array}{l}166.38 \pm \\
19.39 \mathrm{ab}\end{array}$ & $\begin{array}{l}161.6 \pm \\
29.60 \mathrm{~b}\end{array}$ & $\begin{array}{c}141.79 \pm \\
14.12 \mathrm{c}\end{array}$ & $\begin{array}{c}182.81 \pm \\
21.09 \mathrm{a}\end{array}$ & $\begin{array}{c}182.39 \pm \\
21.79 \mathrm{a}\end{array}$ & $\begin{array}{c}123.18 \pm \\
15.94 \mathrm{~d}\end{array}$ & $* * *$ & ns \\
\hline TPC $[\mathrm{mg} / \mathbf{1 0 0} \mathrm{g}]$ & $\begin{array}{l}48.65 \pm \\
7.95 \mathrm{ab}\end{array}$ & $\begin{array}{l}48.27 \pm \\
8.74 \mathrm{ab}\end{array}$ & $\begin{array}{c}46.33 \pm \\
6.48 \mathrm{~b}\end{array}$ & $\begin{array}{c}37.12 \pm \\
7.49 \mathrm{c}\end{array}$ & $\begin{array}{c}52.24 \pm \\
9.96 \mathrm{a}\end{array}$ & $* * *$ & $\begin{array}{c}45.91 \pm \\
7.75 \mathrm{~b}\end{array}$ & $\begin{array}{c}53.06 \pm \\
9.50 \mathrm{a}\end{array}$ & $\begin{array}{c}43.33 \pm \\
6.35 \mathrm{~b}\end{array}$ & $\begin{array}{c}51.15 \pm \\
5.40 \mathrm{a}\end{array}$ & $\begin{array}{c}51.25 \pm \\
8.43 \mathrm{a}\end{array}$ & $\begin{array}{c}34.88 \pm \\
5.52 \mathrm{c}\end{array}$ & $* * *$ & ns \\
\hline
\end{tabular}

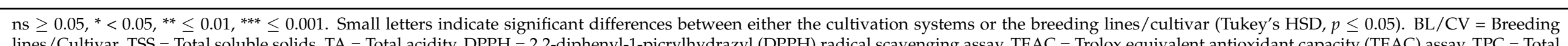

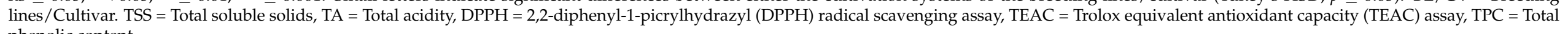
phenolic content. 
Table 4. Mean values \pm standard deviation of minerals in five cultivation systems of five breeding lines and Lyterno $F_{1}$, calculated on fresh matter basis.

\begin{tabular}{|c|c|c|c|c|c|c|c|c|c|c|c|c|c|c|}
\hline \multirow[b]{2}{*}{ [mg/100 g] } & \multicolumn{6}{|c|}{ Cultivation System (CS) } & \multicolumn{7}{|c|}{ Breeding Line (BL)/Cultivar (CV) } & \multirow[t]{2}{*}{$\mathrm{BL} / \mathrm{CV} \times \mathrm{CS}$} \\
\hline & 1 & 2 & 3 & 4 & 5 & & 1 & 2 & 3 & 4 & 5 & 6 & & \\
\hline $\mathrm{Ca}$ & $\begin{array}{l}7.9 \pm \\
1.69 \mathrm{~b}\end{array}$ & $\begin{array}{l}7.82 \pm \\
1.87 \mathrm{~b}\end{array}$ & $\begin{array}{l}7.23 \pm \\
1.28 \mathrm{~b}\end{array}$ & $\begin{array}{l}7.39 \pm \\
1.17 \mathrm{~b}\end{array}$ & $\begin{array}{c}12.27 \pm \\
1.52 \mathrm{a}\end{array}$ & $* * *$ & $\begin{array}{l}9.42 \pm \\
2.77 \mathrm{a}\end{array}$ & $\begin{array}{l}8.76 \pm \\
1.92 \mathrm{a}\end{array}$ & $\begin{array}{l}7.43 \pm \\
2.36 \mathrm{~b}\end{array}$ & $\begin{array}{c}9.07 \pm \\
2.09 \mathrm{a}\end{array}$ & $\begin{array}{l}9.23 \pm \\
2.55 \mathrm{a}\end{array}$ & $\begin{array}{c}7.31 \pm \\
2.18 \mathrm{~b}\end{array}$ & $* * *$ & ns \\
\hline $\mathbf{K}$ & $\begin{array}{c}295.72 \pm \\
49.19 \mathrm{a}\end{array}$ & $\begin{array}{c}285.03 \pm \\
38.08 \mathrm{a}\end{array}$ & $\begin{array}{c}293.74 \pm \\
47.42 \mathrm{a}\end{array}$ & $\begin{array}{c}280.11 \pm \\
49.79 \mathrm{a}\end{array}$ & $\begin{array}{c}200.87 \pm \\
24.84 \mathrm{~b}\end{array}$ & $* * *$ & $\begin{array}{c}233.56 \pm \\
38.81 \mathrm{c}\end{array}$ & $\begin{array}{c}284.17 \pm \\
43.16 \mathrm{~b}\end{array}$ & $\begin{array}{c}267.29 \pm \\
38.85 \mathrm{~b}\end{array}$ & $\begin{array}{c}286.31 \pm \\
56.23 \mathrm{~b}\end{array}$ & $\begin{array}{c}323.07 \pm \\
56.64 \mathrm{a}\end{array}$ & $\begin{array}{c}228.7 \pm \\
36.67 c\end{array}$ & $* * *$ & $* *$ \\
\hline Mg & $\begin{array}{c}11.98 \pm \\
2.18 \mathrm{a}\end{array}$ & $\begin{array}{c}12.01 \pm \\
2.12 \mathrm{a}\end{array}$ & $\begin{array}{c}12.34 \pm \\
2.62 \mathrm{a}\end{array}$ & $\begin{array}{c}11.84 \pm \\
2.75 \mathrm{a}\end{array}$ & $\begin{array}{l}9.25 \pm \\
1.81 \mathrm{~b}\end{array}$ & $* * *$ & $\begin{array}{c}9.65 \pm \\
1.77 \mathrm{c}\end{array}$ & $\begin{array}{c}10.61 \pm \\
1.24 \mathrm{~b}\end{array}$ & $\begin{array}{c}11.13 \pm \\
1.32 \mathrm{~b}\end{array}$ & $\begin{array}{c}14.34 \pm \\
2.17 \mathrm{a}\end{array}$ & $\begin{array}{c}14.03 \pm \\
1.59 \mathrm{a}\end{array}$ & $\begin{array}{c}9.17 \pm \\
1.24 \mathrm{c}\end{array}$ & $* * *$ & * \\
\hline $\mathbf{P}$ & $\begin{array}{c}47.94 \pm \\
6.56 \mathrm{a}\end{array}$ & $\begin{array}{c}47.25 \pm \\
6.06 \mathrm{a}\end{array}$ & $\begin{array}{c}47.28 \pm \\
6.79 \mathrm{a}\end{array}$ & $\begin{array}{c}45.33 \pm \\
7.63 \mathrm{a}\end{array}$ & $\begin{array}{c}37.99 \pm \\
6.49 \mathrm{~b}\end{array}$ & $* * *$ & $\begin{array}{c}42.73 \pm \\
5.45 \mathrm{~b}\end{array}$ & $\begin{array}{c}48.31 \pm \\
4.71 \mathrm{a}\end{array}$ & $\begin{array}{l}43.5 \pm \\
5.60 \mathrm{~b}\end{array}$ & $\begin{array}{c}50.32 \pm \\
6.62 \mathrm{a}\end{array}$ & $\begin{array}{c}50.87 \pm \\
4.62 \mathrm{a}\end{array}$ & $\begin{array}{c}35.08 \pm \\
4.62 \mathrm{c}\end{array}$ & $* * *$ & $* *$ \\
\hline $\mathbf{N}$ & $\begin{array}{c}5.81 \pm \\
0.82 \mathrm{a}\end{array}$ & $\begin{array}{c}5.47 \pm \\
0.63 \mathrm{a}\end{array}$ & $\begin{array}{c}5.52 \pm \\
0.66 \mathrm{a}\end{array}$ & $\begin{array}{c}5.48 \pm \\
0.91 \mathrm{a}\end{array}$ & $\begin{array}{l}4.78 \pm \\
0.71 \mathrm{~b}\end{array}$ & $* * *$ & $\begin{array}{c}5.13 \pm \\
0.50 \mathrm{~b}\end{array}$ & $\begin{array}{c}5.86 \pm \\
0.70 \mathrm{a}\end{array}$ & $\begin{array}{l}5.00 \pm \\
0.52 \mathrm{~b}\end{array}$ & $\begin{array}{c}6.00 \pm \\
0.68 \mathrm{a}\end{array}$ & $\begin{array}{c}5.95 \pm \\
0.61 \mathrm{a}\end{array}$ & $\begin{array}{l}4.5 \pm \\
0.55 c\end{array}$ & $* * *$ & * \\
\hline $\mathrm{Fe}$ & $\begin{array}{c}0.74 \pm \\
0.28\end{array}$ & $\begin{array}{c}0.63 \pm \\
0.19\end{array}$ & $\begin{array}{c}0.64 \pm \\
0.20\end{array}$ & $\begin{array}{c}0.64 \pm \\
0.31\end{array}$ & $0.6 \pm 0.18$ & $\mathrm{~ns}$ & $\begin{array}{l}0.56 \pm \\
0.10 \mathrm{~cd}\end{array}$ & $\begin{array}{l}0.67 \pm \\
0.14 \mathrm{bc}\end{array}$ & $\begin{array}{c}0.6 \pm \\
0.30 \mathrm{bcd}\end{array}$ & $\begin{array}{c}0.86 \pm \\
0.28 \mathrm{a}\end{array}$ & $\begin{array}{l}0.75 \pm \\
0.14 \mathrm{ab}\end{array}$ & $\begin{array}{l}0.44 \pm \\
0.14 \mathrm{~d}\end{array}$ & $* * *$ & ns \\
\hline $\mathbf{M}$ & $\begin{array}{c}0.29 \pm \\
0.09 \mathrm{a}\end{array}$ & $\begin{array}{c}0.29 \pm \\
0.10 a\end{array}$ & $\begin{array}{c}0.26 \pm \\
0.08 \mathrm{a}\end{array}$ & $\begin{array}{c}0.26 \pm \\
0.06 \mathrm{a}\end{array}$ & $\begin{array}{l}0.08 \pm \\
0.02 \mathrm{~b}\end{array}$ & $* * *$ & $\begin{array}{c}0.24 \pm \\
0.10 \mathrm{~b}\end{array}$ & $\begin{array}{c}0.25 \pm \\
0.12 \mathrm{~b}\end{array}$ & $\begin{array}{l}0.2 \pm \\
0.07 \mathrm{c}\end{array}$ & $\begin{array}{c}0.31 \pm \\
0.12 \mathrm{a}\end{array}$ & $\begin{array}{c}0.26 \pm \\
0.10 \mathrm{~b}\end{array}$ & $\begin{array}{c}0.17 \pm \\
0.07 c\end{array}$ & $* * *$ & $* * *$ \\
\hline
\end{tabular}

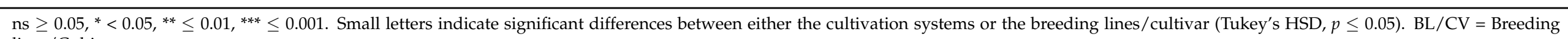
lines/Cultivar. 
3.3. Influence of Glass Cover and Supplementary LED Interlighting on Yield, Fruit Quality, and Flavor Compounds

Since the differences in the growing conditions between the hydroponic cultivation systems and the organic cultivation system are high, we took a closer look at the four hydroponic cultivation systems, which differ only in the covering (single glazing or double glazing), or the additional interlighting in the form of LED lamps. Most yield parameters showed significant differences between the two glass covers and the additional interlighting (Table 5). Plants grown in the single-glazed greenhouse were significantly shorter than plants grown in the double-glazed greenhouse (Table 5). The supplementary interlighting had a significant influence on the length as well, with smaller plants in the cultivation systems with additional interlighting (Table 5), while leaf development was not affected. The truss development and the fruit yield were significantly higher for plants in the singleglazed cultivation systems (CS 1 and 2), and in the cultivation systems with additional interlighting (CS 1 and 3) compared to the combination of double glazing without additional interlighting (Table 5). For the fruit quality parameters DM and TSS, only the glazing system had a significant impact on the fruits, but not the supplementary interlighting (Table 6). The values were significantly higher in fruits from the single-glazed greenhouse (CS 1 and 2) than in the double-glazed greenhouse (CS 3 and 4). The TA content, $\mathrm{pH}$ value, $a^{*}$ value, and the hue angle did not show significant differences in the fruits comparing the factors lighting and glazing (Table 6). The DPPH and TEAC values and the TPC were significantly lower in the fruits from the double-glazed greenhouse (Table 6). TPC was lower in fruits from the cultivation systems without additional interlighting, while no significant difference was found for DPPH and TEAC (Table 6). The influence of the two greenhouse glazing systems and the additional interlighting on the mineral concentrations in the fruits is not easy to explain because a significant interaction between breeding lines (BL)/cultivar (CV) and the glazing (G) could be found (Table 6). Mineral concentration of the fruits, comparing the two glazing types, was mostly dependent on the breeding line/cultivar. The aroma compounds 1-hexanol, Z-3-hexenol, benzaldehyde, and 2-phenylethanol showed significantly lower relative amounts from fruits in the cultivation systems without supplementary interlighting (Table 7). E-2-hexenal, Z-3-hexenol, and $B$-damascenone had significantly lower relative concentrations in the fruits from the single-glazed greenhouse, while benzaldehyde, neral, and geranial showed significantly higher relative concentrations in the fruits (Table 7).

3.4. Comparison of Fruits from CSs with and without Supplementary LED Interlighting in Terms of Sensory Analysis and Their Metabolite Profile in Single Glazing and Double Glazing

Sensory analysis was conducted with fruits from the single-glazed greenhouse with and without additional LED interlighting (CS 1 and 2); they did not show significant differences in the sensory attributes (Table S4). Since higher differences between quality parameters due to different glazing systems were found, we focused on the fruits of these two cultivation systems and selected two salad-type breeding lines and the cultivar Lyterno $F_{1}$ for metabolite analysis. We compared the metabolite profile from the fruits in the two cultivation systems. Fruits from the single-glazed greenhouse (CS 2) and the double-glazed greenhouse (CS 4) - both without additional LED interlighting-showed significant differences in the amounts of some amino acids and two sugars (Figure 2). We found that the significant different concentrations always indicated a lower production of metabolites in fruits from the double-glazed cultivation system (CS 4) compared to the single-glazed cultivation system (CS 2) (Figure 2; Table S5). 


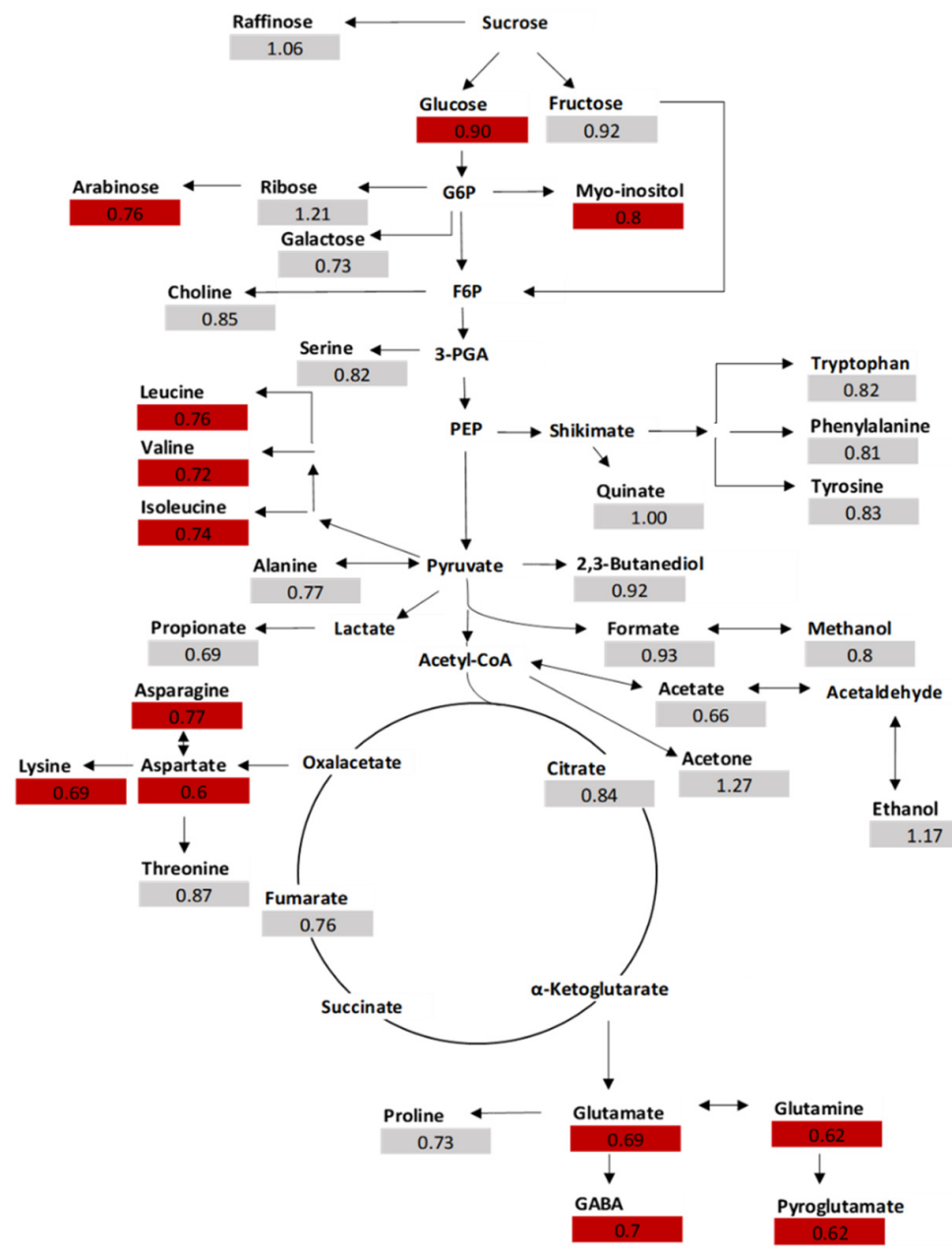

$\operatorname{cs} 4 / \operatorname{cs} 2$

Red: significant decrease $(p<0.05)$

Figure 2. Fold changes (FC) of metabolites from fruits of CS 4 (double glazing greenhouse without LED) compared to fruits of CS 2 (single glazing greenhouse without LED) of two breeding lines (170, 157) and Lyterno $F_{1}($ each $n=3)(t$-test $p \leq 0.05)$. Glucose and Fructose were analyzed with HPLC.

Table 5. Mean values \pm standard deviation of agronomic traits of the five breeding lines and Lyterno $\mathrm{F}_{1}$, distinguished between single-glazed and double-glazed greenhouses, or with and without supplementary LED lighting.

\begin{tabular}{|c|c|c|c|c|c|c|c|c|c|c|c|}
\hline & \multicolumn{3}{|c|}{ Glazing (G) } & \multicolumn{3}{|c|}{ Lighting (L) } & \multirow[t]{2}{*}{$\mathrm{BL} / \mathrm{CV}$} & \multirow[t]{2}{*}{$\begin{array}{l}\mathrm{BL} / \mathrm{CV} \\
\times \mathrm{G}\end{array}$} & \multirow[t]{2}{*}{$\begin{array}{l}\mathrm{BL} / \mathrm{CV} \\
\times \mathrm{L}\end{array}$} & \multirow[t]{2}{*}{$\underset{\mathrm{L}}{\mathrm{G} \times}$} & \multirow[t]{2}{*}{$\begin{array}{r}\mathrm{BL} / \mathrm{CV} \\
\times \mathrm{G} \times \mathrm{L}\end{array}$} \\
\hline & $\begin{array}{l}\text { Single } \\
\text { Glazing }\end{array}$ & $\begin{array}{l}\text { Double } \\
\text { Glazing }\end{array}$ & & without & with & & & & & & \\
\hline length [m] & $3.31 \pm 0.30$ & $3.44 \pm 0.34$ & $* *$ & $3.43 \pm 0.32$ & $3.31 \pm 0.32$ & * & $* * *$ & ns & ns & ns & ns \\
\hline leaves up to truss 3 & $3.12 \pm 0.40$ & $3.13 \pm 0.48$ & ns & $3.16 \pm 0.53$ & $3.09 \pm 0.34$ & ns & $* * *$ & ns & ns & * & ns \\
\hline trusses up to $2.5 \mathrm{~m}$ & $9.16 \pm 1.34$ & $8.7 \pm 1.25$ & $* *$ & $8.59 \pm 1.19$ & $9.27 \pm 1.34$ & $* * *$ & $* * *$ & ns & ns & ns & ns \\
\hline $\begin{array}{l}\text { trusses per week } \\
\text { since planting }\end{array}$ & $0.91 \pm 0.13$ & $0.88 \pm 0.14$ & ns & $0.86 \pm 0.14$ & $0.93 \pm 0.12$ & $* * *$ & $* * *$ & * & ns & * & ns \\
\hline $\begin{array}{l}\text { trusses whole plant } \\
\text { time from planting }\end{array}$ & $12.52 \pm 1.50$ & $12.08 \pm 1.33$ & * & $11.95 \pm 1.54$ & $12.65 \pm 1.23$ & $* *$ & $* * *$ & ns & ns & $* *$ & ns \\
\hline $\begin{array}{l}\text { to } 2.5 \mathrm{~m} \text { plant } \\
\text { height [weeks] }\end{array}$ & $10.2 \pm 0.93$ & $9.9 \pm 0.93$ & * & $10.01 \pm 0.99$ & $10.09 \pm 0.90$ & ns & $* * *$ & ns & ns & ns & ns \\
\hline single fruit & $58.11 \pm 29.18$ & $52.09 \pm 25.71$ & $* *$ & $52.64 \pm 25.53$ & $57.56 \pm 29.43$ & $* *$ & $* * *$ & ns & $* *$ & * & ns \\
\hline $\begin{array}{l}\text { yield [g per week } \\
\text { and plant since } \\
\text { planting] }\end{array}$ & $327.36 \pm 150.21$ & $282.48 \pm 131.37$ & $* * *$ & $282.17 \pm 128.99$ & $327.66 \pm 152.17$ & $* * *$ & $* * *$ & ns & ns & ns & ns \\
\hline $\begin{array}{l}\text { calculated yield } \\
\text { [kg per plant] }\end{array}$ & $3.23 \pm 1.33$ & $2.68 \pm 1.01$ & $* * *$ & $2.75 \pm 1.09$ & $3.17 \pm 1.30$ & $* * *$ & $* * *$ & * & ns & * & * \\
\hline
\end{tabular}

ns $\geq 0.05,{ }^{*}<0.05,{ }^{* *} \leq 0.01,{ }^{* * *} \leq 0.001$ based on three-way ANOVA. BL/CV = Breeding lines/Cultivar. 
Table 6. Mean values \pm standard deviation of quality parameters, fructose and glucose content, antioxidant capacity, total phenolic content, and minerals of five breeding lines and Lyterno $F_{1}$, distinguished between single-glazed and double-glazed greenhouses, or with and without supplementary LED lighting.

\begin{tabular}{|c|c|c|c|c|c|c|c|c|c|c|c|}
\hline & \multicolumn{3}{|c|}{ Glazing (G) } & \multicolumn{3}{|c|}{ Lighting (L) } & \multirow[t]{2}{*}{$\mathrm{BL} / \mathrm{CV}$} & \multirow[t]{2}{*}{$\begin{array}{c}\mathrm{BL} / \mathrm{CV} \\
\times \mathrm{G}\end{array}$} & \multirow[t]{2}{*}{$\begin{array}{c}\mathrm{BL} / \mathrm{CV} \\
\times \mathrm{L}\end{array}$} & \multirow[t]{2}{*}{$\underset{\mathrm{L}}{\mathrm{G} \times}$} & \multirow[t]{2}{*}{$\begin{array}{c}\mathrm{BL} / \mathrm{CV} \\
\times \mathrm{G} \times \mathrm{L}\end{array}$} \\
\hline & $\begin{array}{l}\text { Single } \\
\text { Glazing }\end{array}$ & $\begin{array}{l}\text { Double } \\
\text { Glazing }\end{array}$ & & without & with & & & & & & \\
\hline Dry matter [\%] & $7.27 \pm 1.23$ & $6.73 \pm 1.18$ & $* * *$ & $6.9 \pm 1.39$ & $7.11 \pm 1.06$ & ns & $* * *$ & $* * *$ & ns & ns & ns \\
\hline TSS $\left[{ }^{\circ}\right.$ Brix $]$ & $6.67 \pm 1.13$ & $6.17 \pm 1.02$ & $* *$ & $6.46 \pm 1.20$ & $6.38 \pm 1.01$ & ns & $* * *$ & ns & ns & ns & ns \\
\hline TA [\%] & $0.58 \pm 0.15$ & $0.57 \pm 0.14$ & ns & $0.57 \pm 0.15$ & $0.57 \pm 0.14$ & ns & $* * *$ & ns & ns & ns & ns \\
\hline $\mathrm{pH}$ & $4.23 \pm 0.16$ & $4.21 \pm 0.14$ & ns & $4.24 \pm 0.17$ & $4.21 \pm 0.14$ & ns & $* * *$ & ns & ns & ns & ns \\
\hline$a^{*}$ value & $13.98 \pm 4.46$ & $13.8 \pm 4.33$ & ns & $13.76 \pm 4.45$ & $14.02 \pm 4.34$ & ns & $* * *$ & * & ns & ns & ns \\
\hline Hue angle $\left[{ }^{\circ}\right]$ & $61.93 \pm 5.15$ & $62.45 \pm 5.06$ & ns & $62.15 \pm 5.41$ & $62.23 \pm 4.81$ & ns & $* * *$ & * & ns & ns & ns \\
\hline Fructose $[g / 100 g]$ & $1.93 \pm 0.39$ & $1.81 \pm 0.35$ & $* * *$ & $1.87 \pm 0.43$ & $1.86 \pm 0.32$ & ns & $* * *$ & $* * *$ & ns & $* *$ & * \\
\hline Glucose $[\mathrm{g} / 100 \mathrm{~g}]$ & $1.75 \pm 0.39$ & $1.61 \pm 0.33$ & $* * *$ & $1.69 \pm 0.42$ & $1.67 \pm 0.30$ & ns & $* * *$ & $* *$ & ns & * & * \\
\hline $\begin{array}{l}\text { DPPH } \\
{[\mu \mathrm{mol} / 100 \mathrm{~g}]}\end{array}$ & $139.32 \pm 28.20$ & $121.91 \pm 24.70$ & $* * *$ & $130.22 \pm 29.76$ & $131.18 \pm 26.05$ & ns & $* * *$ & ns & ns & ns & ns \\
\hline $\begin{array}{l}\text { TEAC } \\
{[\mu \mathrm{mol} / 100 \mathrm{~g}]}\end{array}$ & $169.4 \pm 31.82$ & $153.29 \pm 27.27$ & $* * *$ & $162.03 \pm 33.59$ & $160.84 \pm 27.69$ & ns & $* * *$ & ns & ns & * & ns \\
\hline TPC $[\mathrm{mg} / 100 \mathrm{~g}]$ & $48.46 \pm 8.27$ & $41.82 \pm 8.34$ & $* * *$ & $42.81 \pm 9.84$ & $47.49 \pm 7.27$ & $* * *$ & $* * *$ & $* *$ & ns & $* * *$ & ns \\
\hline $\mathrm{Ca}[\mathrm{mg} / \mathbf{1 0 0} \mathrm{g}]$ & $7.86 \pm 1.76$ & $7.3 \pm 1.22$ & * & $7.6 \pm 1.56$ & $7.57 \pm 1.52$ & ns & $* * *$ & ns & ns & ns & ns \\
\hline $\mathrm{K}[\mathrm{mg} / 100 \mathrm{~g}]$ & $290.37 \pm 43.85$ & $287.07 \pm 48.55$ & ns & $282.62 \pm 43.78$ & $294.73 \pm 47.81$ & $*$ & $* * *$ & $* *$ & ns & ns & ns \\
\hline $\mathrm{Mg}[\mathrm{mg} / 100 \mathrm{~g}]$ & $12 \pm 2.12$ & $12.16 \pm 2.66$ & ns & $11.99 \pm 2.42$ & $12.16 \pm 2.39$ & ns & $* * *$ & $* *$ & ns & ns & ns \\
\hline$P[\mathrm{mg} / 100 \mathrm{~g}]$ & $47.59 \pm 6.26$ & $46.33 \pm 7.20$ & $*$ & $46.31 \pm 6.87$ & $47.61 \pm 6.61$ & * & $* * *$ & $* * *$ & ns & ns & ns \\
\hline $\mathrm{Na}[\mathrm{mg} / 100 \mathrm{~g}]$ & $5.64 \pm 0.75$ & $5.5 \pm 0.79$ & ns & $5.47 \pm 0.77$ & $5.66 \pm 0.75$ & * & $* * *$ & $* *$ & ns & ns & ns \\
\hline $\mathrm{Fe}[\mathrm{mg} / 100 \mathrm{~g}]$ & $0.68 \pm 0.24$ & $0.64 \pm 0.25$ & ns & $0.64 \pm 0.25$ & $0.69 \pm 0.24$ & ns & $* * *$ & ns & ns & ns & ns \\
\hline $\mathrm{Mn}[\mathrm{mg} / 100 \mathrm{~g}]$ & $0.29 \pm 0.09$ & $0.26 \pm 0.07$ & * & $0.28 \pm 0.08$ & $0.28 \pm 0.08$ & ns & $* * *$ & $* *$ & ns & ns & ns \\
\hline
\end{tabular}

ns $\geq 0.05,{ }^{*}<0.05,{ }^{* *} \leq 0.01,{ }^{* * *} \leq 0.001$ based on three-way ANOVA. BL/CV = Breeding lines/Cultivar. TSS = Total soluble solids, $\mathrm{TA}=$ Total acidity, $\mathrm{DPPH}=2,2$-diphenyl-1-picrylhydrazyl (DPPH) radical scavenging assay, TEAC = Trolox equivalent antioxidant capacity (TEAC) assay, TPC $=$ Total phenolic content.

Table 7. Mean values \pm standard deviation of 18 aroma compounds of five breeding lines and Lyterno $\mathrm{F}_{1}$, distinguished between single-glazed and double-glazed greenhouses or with and without supplementary LED lighting.

\begin{tabular}{|c|c|c|c|c|c|c|c|c|c|c|c|}
\hline \multirow[b]{2}{*}{ [ng/mL sample] } & \multicolumn{3}{|c|}{ Glazing (G) } & \multicolumn{3}{|c|}{ Lighting (L) } & \multirow[t]{2}{*}{$\mathrm{BL} / \mathrm{CV}$} & \multirow[t]{2}{*}{$\begin{array}{c}\mathrm{BL} / \mathrm{CV} \\
\times \mathrm{G}\end{array}$} & \multirow[t]{2}{*}{$\begin{array}{l}\mathrm{BL} / \mathrm{CV} \\
\times \mathrm{L}\end{array}$} & \multirow[t]{2}{*}{$\underset{\mathrm{L}}{\mathrm{G} \times}$} & \multirow[t]{2}{*}{$\begin{array}{r}\mathrm{BL} / \mathrm{CV} \\
\times \mathrm{G} \times \mathrm{L}\end{array}$} \\
\hline & $\begin{array}{l}\text { Single } \\
\text { Glazing }\end{array}$ & $\begin{array}{l}\text { Double } \\
\text { Glazing }\end{array}$ & & without & with & & & & & & \\
\hline 1-Penten-3-one & $0.01 \pm 0.00$ & $0.01 \pm 0.00$ & ns & $0.01 \pm 0.00$ & $0.01 \pm 0.00$ & ns & $* * *$ & ns & ns & ns & ns \\
\hline Hexanal & $6.24 \pm 3.71$ & $7.59 \pm 4.93$ & ns & $6.92 \pm 3.76$ & $6.92 \pm 4.98$ & ns & $* * *$ & ns & ns & * & ns \\
\hline Z-3-Hexenal & $1.59 \pm 0.69$ & $1.46 \pm 0.70$ & ns & $1.27 \pm 0.55$ & $1.78 \pm 0.73$ & $* * *$ & $* * *$ & ns & ns & * & ns \\
\hline E-2-Hexenal & $3.98 \pm 1.99$ & $4.61 \pm 1.96$ & $* * *$ & $3.86 \pm 1.74$ & $4.73 \pm 2.14$ & $* * *$ & $* * *$ & ns & ns & $* * *$ & ns \\
\hline $\begin{array}{l}\text { 6-Methyl-5-hepten- } \\
\text { 2-one }\end{array}$ & $2.87 \pm 1.28$ & $2.74 \pm 1.15$ & ns & $2.7 \pm 1.16$ & $2.9 \pm 1.27$ & ns & ns & ns & ns & ns & ns \\
\hline 1-Hexanol & $0.14 \pm 0.09$ & $0.12 \pm 0.08$ & ns & $0.15 \pm 0.10$ & $0.1 \pm 0.07$ & $* * *$ & $* * *$ & ns & ns & ns & ns \\
\hline Z-3-Hexenol & $0.22 \pm 0.05$ & $0.23 \pm 0.04$ & $*$ & $0.24 \pm 0.04$ & $0.21 \pm 0.05$ & $* * *$ & $* * *$ & ns & ns & ns & ns \\
\hline 2-Isobutylthiazole & $2.19 \pm 2.15$ & $2.14 \pm 1.44$ & ns & $2.19 \pm 2.00$ & $2.14 \pm 1.64$ & ns & $* * *$ & $* *$ & $\mathrm{~ns}$ & ns & ns \\
\hline Benzaldehyde & $0.15 \pm 0.05$ & $0.13 \pm 0.06$ & $* *$ & $0.16 \pm 0.06$ & $0.13 \pm 0.05$ & $* *$ & $* * *$ & $* * *$ & ns & $*$ & ns \\
\hline Phenylacetaldeyde & $0.09 \pm 0.03$ & $0.08 \pm 0.03$ & ns & $0.08 \pm 0.03$ & $0.08 \pm 0.04$ & ns & $* * *$ & ns & $*$ & $* *$ & ns \\
\hline Neral & $0.05 \pm 0.04$ & $0.04 \pm 0.03$ & $* *$ & $0.05 \pm 0.04$ & $0.05 \pm 0.03$ & ns & $* * *$ & ns & ns & ns & ns \\
\hline Geranial & $0.31 \pm 0.16$ & $0.23 \pm 0.14$ & $* * *$ & $0.21 \pm 0.11$ & $0.32 \pm 0.17$ & $* * *$ & ns & ns & ns & $* * *$ & ns \\
\hline Methyl salicylate & $0.15 \pm 0.27$ & $0.09 \pm 0.12$ & ns & $0.14 \pm 0.26$ & $0.1 \pm 0.14$ & ns & $* * *$ & ns & ns & ns & ns \\
\hline B-Damascenone & $0.15 \pm 0.10$ & $0.2 \pm 0.17$ & $*$ & $0.18 \pm 0.15$ & $0.18 \pm 0.14$ & ns & $* * *$ & $*$ & ns & ns & ns \\
\hline Z-Geranylacetone & $0.02 \pm 0.01$ & $0.02 \pm 0.01$ & ns & $0.02 \pm 0.01$ & $0.02 \pm 0.01$ & $* *$ & $* * *$ & * & ns & ns & ns \\
\hline E-Geranylacetone & $2.13 \pm 1.10$ & $2.07 \pm 1.10$ & ns & $1.91 \pm 0.95$ & $2.27 \pm 1.20$ & ns & $* * *$ & ns & $*$ & ns & ns \\
\hline 2-Phenylethanol & $0.42 \pm 0.18$ & $0.4 \pm 0.18$ & ns & $0.45 \pm 0.21$ & $0.36 \pm 0.14$ & $* * *$ & $* * *$ & ns & ns & ns & ns \\
\hline B-Ionone & $0.34 \pm 0.20$ & $0.33 \pm 0.20$ & ns & $0.28 \pm 0.14$ & $0.39 \pm 0.23$ & $* * *$ & $* * *$ & ns & ns & ns & ns \\
\hline
\end{tabular}

$\mathrm{ns} \geq 0.05,{ }^{*}<0.05,{ }^{* *} \leq 0.01,{ }^{* * *} \leq 0.001$ based on three-way ANOVA. BL/CV $=$ Breeding lines/Cultivar.

\section{Discussion}

\subsection{Comparison of the Cultivation Systems}

Light emitting diodes (LEDs) are expected to become the main lighting technology in horticulture because of their technical properties; higher energy efficiency, selectable spectrum, and a cool photon-emitting surface [22]. This has already been shown by a growing sector of horticultural LED production [23]. We compared yield, fruit nutritional, and quality parameters from the fruits of five new breeding lines and Lyterno $F_{1}$ in four different intensive cultivation systems and an organic low-input production system on the field. We wanted to determine the extent to which the new breeding lines and Lyterno $\mathrm{F}_{1}$ are influenced by different cultivation systems and to describe the differences of the 
cultivation systems that might have led to fruit composition changes. Experiments were performed during the outdoor tomato season with high solar radiation to integrate the organic low-input cultivation system, though it can be supposed that the effect of glazing and supplemental LED interlighting could have been more significant during the off season. This assumption is supported by Tewolde et al. [24], who found a higher influence of supplemental LED interlighting during winter production compared to summer production.

\subsubsection{Climatic Differences among the Cultivation Systems}

The double glazing system is an approach in horticultural production, known as lowenergy greenhouses, which reduces the heating costs during production. As transmissivity is reduced by $10-15 \%$ compared to commonly used single-pane glass, it is discussed how the cultivation system could be adapted to maintain healthy plants and product quality [16] In our study, the calculated light transmissivity in the double-glazed greenhouse showed a reduced light intensity of $8 \%$ compared to the single-glazed greenhouse. A rough 'rule of thumb' is that a reduction of $1 \%$ in PAR transmittance of a greenhouse cover results in an $1 \%$ reduction in yield [25]. Supplementary lighting is a possible way to compensate reduced light levels in tomato production, especially during the off season (autumn-winter) in northern climates, to provide locally grown and fresh tomatoes year round [10]. In addition, it is an opportunity to fine-tune tomato production by increasing the fruit quality and its nutritional value with supplementary lighting [22]. The vapor pressure deficit (VPD) is a suitable indicator for the ratio of root pressure and transpiration suction in the xylem vessels. Due to this, it is a good indicator to optimize fruit development [9]. In the organic cultivation system (CS 5), $41.4 \%$ of the VPD values occurred in the low range, which means that a low transpiration and a relatively higher root pressure could be assumed for that time. Generally, optimum values for temperature, relative humidity, and VPD were obtained more often in the greenhouse systems (CS 1-4) than in the organic system (CS 5). In CS 5, both parameters were frequently in a range that could be estimated as too cold and too wet, resulting in a low VPD, which can prevent transpiration and enhance root pressure, as discussed by Gruda [8]. In our study, low VPD mainly occurred at night (data not shown) in all cultivation systems, but, because of open sidewalls in the organic system (CS 5), values got close to outdoor conditions and could hardly be controlled. As discussed by Bradfield and Guttridge [26], high humidity and VPD at night can enhance the calcium content in the fruits, which was also found in the present study. Fruits from CS 5 showed significantly higher calcium concentrations compared to CS 1-4. By controlling VPD, the calcium content in the fruits can be influenced and therefore be used for quality enhancement in tomato production. On the other hand, extreme environmental conditions can lead either to calcium excess or deficiency in the fruits, which is recognized by 'gold specks' or blossom-end rot [8]. In another study by Rosales et al. [27], environmental stress conditions, such as high VPD, temperature, and solar radiation, have been shown to be the main factors responsible for increasing antioxidant capacity, and other antioxidant parameters such as flavonoids, anthocyanins, and total phenols.

4.1.2. Differences in Yield, Fruit Quality Attributes, and Antioxidant Capacity within the Five Cultivation Systems

The main sugars in tomato fruits are glucose and fructose and their ratio is about 1:1 [28]. However, because fructose is perceived as sweeter, a breeding goal is to increase the fructose concentration in the fruits [28]. The fructose content in fruits of the breeding lines is significantly higher in both cocktail and salad types than in fruits from Lyterno $\mathrm{F}_{1}$ that has larger fruits. The fructose content was significantly lower in fruits from the double-glazed greenhouse without supplementary interlighting (CS 4), compared to those from the organic cultivation system (CS 5) and the single-glazed greenhouse without supplementary LED interlighting (CS2). The sugar content is a widely used attribute to evaluate the sweetness of tomato fruits. However, it has been shown that sugar content alone does not reflect the perception of sweetness; aroma compounds can positively influence sweetness perception [29]. For example, 2-phenylethanol was found to increase 
the perception of sweet taste, aftertaste, and aroma [5], or fruity flavors in combination with sugar, or sugar plus acid [30]. Some apocarotenoid volatiles, especially $B$-ionone and $B$-cyclocitral, were found to positively influence tomato flavor [31]. In the present study, significant differences between fruits from the breeding lines/cultivar could be shown for all aroma compounds that were analyzed, except geranial. The cultivation systems had significant effects on most of the aroma compounds in the fruits except for the relative concentration of 6-methyl-5-hepten-2-one, phenylacetaldehyde, methyl salicylate, and B-damascenone. Cebolla-Cornejo et al. [32], who compared tomato fruits from two environments (open field and screenhouse), did not find significant differences in the concentration of 6-methyl-5-hepten-2-one either. Contrariwise, 6-methyl-5-hepten2-one was found to be significantly different between fruits from net-house and openfield conditions by Lee et al. [33]. Cebolla-Cornejo et al. [32] showed that the aroma compounds, which they referred to as main aroma compounds (Table S3), were significantly influenced by genotype, except 6-methyl-5-hepten-2-one and phenylacetaldehyde, while the environmental differences were evident only for hexanal and methyl salicylate. This shows how difficult it is to find consistent results when such volatile compounds as aroma compounds are considered. Measurements of the antioxidant capacity and TPC in the fruits showed significant differences between the single-glazed greenhouse (CS 1-2), compared to the double-glazed greenhouse without supplementary LED interlighting (CS 4). The TPC was highest in fruits from the organic system (CS 5), but only significantly higher compared to fruits from the double-glazed greenhouse conditions (CS 3-4). The lowest contents for both antioxidant capacity assays and TPC were determined in fruits from the double-glazed greenhouse without LED interlighting (CS 4). A possible reason could be the reduced solar radiation in that cultivation system, which was reduced by $8 \%$ in contrast to the single-glazed cultivation systems (CS 1 and 2). Furthermore, Gautier et al. [34] showed that fruit irradiance during ripening increases antioxidants in fruits. Martínez-Valverde et al. [2] found that the antioxidant activity in fruits correlated with the contents of total phenolics, which is in accordance with this study, and that it varies between the cultivars, which can also be confirmed by the present results. Considering the mineral content, potassium and phosphate make up the largest proportion of minerals in tomatoes [35], which is also seen in the present study, whereas we calculated phosphorous not phosphate. Costa et al. [36] compared the mineral concentrations of the different tomato types-including cherry, elongated, and round-during the ripening process after harvest. They found that cherry tomatoes revealed the highest mineral concentrations among the three types, which is similar to our study, where the breeding lines with the smaller-sized fruits showed higher mineral contents, especially compared to Lyterno $F_{1}$. Hernández Suárez et al. [37] showed that the influence of the cultivation method (intensive, organic, and hydroponic) on the macro- and microelement concentrations in the fruits depends mainly on the cultivar. The five cultivation systems in the present study were covered with either glass or plastic cover. Thus, UV-B and UV-A radiation was not transmitted through either the glass or the field cover, which could affect physicochemical parameters, although in a study conducted by Dzakovich et al. [38], no actual alteration of secondary metabolic processes was found, because of the addition of environmentally relevant doses of UV-B. The results in the abovementioned study pointed out the possibilities of $U V$ responses to alter the flavor of greenhouse-grown tomatoes.

\subsection{Effects of Single Glazing and Double Glazing and Additional LED Interlighting}

Several studies about different additional lighting or light spectra and their influence on yield or fruit parameters have been published [10,39], but no publication about the effect of single glazing or double glazing on fruit quality could be found. We took a closer look at the factors glazing and supplemental LED interlighting and investigated a variety of parameters that influence taste and aroma, as well as yield parameters, the nutritional value of the fruits, and how they are affected by these two factors. 
4.2.1. Yield Parameters, Fruit Quality Attributes, Total Phenolic Content, and Antioxidant Capacity

The plant height was significantly affected by glazing and supplemental LED interlighting, showing that plants in the single-glazed greenhouse or with additional LED interlighting were smaller than plants in the double-glazed greenhouse or without additional LED interlighting. This was in accordance with the number of trusses and the yield, which were significantly higher in fruits from the single-glazed greenhouse or with additional LED interlighting. Comparing the influence of the single glazing and double glazing and the additional LED interlighting on some fruit quality parameters it was shown that the glazing had a greater impact on mineral and total phenolic content and antioxidant capacity during the growing season than the additional LED interlighting. We found significantly higher dry matter, TSS, and fructose and glucose contents in fruits from the single-glazed greenhouse. The same was determined for the total phenolic content and the antioxidant capacity (DPPH and TEAC). An effect of the additional LED interlighting was only obvious for the total phenolic, potassium, phosphor, and sodium contents. The cultivation systems - either glazing or additional LED interlighting — did not significantly affect the TA content or the $a$-value or the hue angle from the fruits but were shown to be cultivar-dependent. Dzakovich et al. [39], found that supplementary lighting from red, blue, and far red LEDs did not significantly affect the physiochemical or sensory properties of greenhouse tomatoes. They suggest that fruits that were harvested in a time were solar DLI (daily light integral) contributing substantially to the total amount of the light received by plants, may reduce the effect of supplemental lighting. This explanation could also be a reason why the light effect in our study was less pronounced than in other studies that conducted the experiments during winter, where additional light can have a much higher influence on fruit quality. For example, Kowalczyk et al. [40] reported that plants grown under supplementary lighting were rated sweeter than fruits from plants with no supplementary lighting. However, the study was conducted during the autumn-winter cultivation. In the double-glazed cultivation systems, a lower concentration of most quality parameters was found in the fruits. The lower light transmittance in the double-glazed greenhouse system could explain the lower fruit quality. A decrease in PAR transmission can reduce fruit yield and quality $[14,25]$. Nevertheless, it could be seen that the additional LED interlighting could lower the negative effect of the double glazing. Gautier et al. [34] showed that fruit temperature and irradiance affected antioxidant compounds. Again, whereas fruit irradiance stimulated the synthesis of some compounds known for their antioxidant activity, increased fruit temperature had contrasting effects, except for the rutin content. The application of LED interlighting may be useful to reduce the negative temperature effect because of their low heat transmission, allowing supplemental lighting on the fruit level, with limited altering of the microclimate [24]. The genotype, glazing and supplementary LED interlighting affect the relative concentration of different volatiles in tomato fruits. There was no consistent trend in the relative concentrations of the aroma compounds, either with glazing or with supplemental LED interlighting, and some interactions occurred. The relative geranial concentration was found to be significantly higher in fruits from single-glazed greenhouse and with additional LED interlighting.

4.2.2. Effect of Supplemental LED Interlighting on Sensory Analysis and the Metabolite Profile in Single Glazing and Double Glazing

The sensory panel revealed no significant difference between the studied sensory attributes within the fruits of the single-glazed cultivation systems, with and without supplemental LED interlighting (CS 1 and 2). However, significant differences in the overall flavor, fruity flavor, sweetness, sourness, juiciness, firmness, and aftertaste were found between the breeding lines/cultivar. The additional LED interlighting during the in season in tomato production does not seem to increase the perceivable fruit quality in this case. Metabolite analyses in fruits from two breeding lines and Lyterno $\mathrm{F}_{1}$ showed that glutamate was the most abundant amino acid. In general, glutamate, glutamine, aspartic acid, and GABA ( $\gamma$-aminobutiric acid) are the quantitatively most important 
free amino acids in tomato fruits [35,41]. The comparison between the fruits from the two cultivation systems showed significant differences in some metabolites, mainly amino acids. The fruits grown in the double-glazed greenhouse showed a significant decrease in the concentrations of arabinose, myo-inositol, leucine, valine, isoleucine, asparagine, aspartate, lysine, glutamate, glutamine, GABA, and pyroglutamate. It might be that the reduced light transmissivity in the double-glazed greenhouse led to the reduction in some metabolites. Glutamate, which is of special interest, as it is known as the fifth basic taste 'umami', and is described as savory [42], significantly decreased in the double-glazed cultivation system (CS 4) compared to the single-glazed cultivation system (CS 2). These findings were in accordance with Biais et al. [43], who assessed the influence of the environment on tomato fruit metabolism under contrasting conditions (water limitation, shading, and optimal for commercial production (control)) and locations. They used a mesh, which removed $60 \%$ of the photosynthetically active radiation and observed that under shading, the amino acid contents decreased strongly compared to the control and the water shortage conditions during cell expansion and ripening. Whereas glutamate content was higher during fruit ripening under water shortage compared to the control, it was lower under shading [43].

\section{Conclusions}

Different glazing, additional LED interlighting, and genotype influence the composition of tomato fruits, their aroma volatile profile, and nutritional value. The genotype has a huge influence on sugar, acid, and mineral content, antioxidant capacity, and relative concentration of aroma compounds, as well as on yield parameters. Selecting breeding lines with high expression of preferred attributes and nutritional value is the first step to achieve good-tasting fruits. In our study, the results of the sensory attributes did not show any significant difference between the single-glazed greenhouse, with and without additional LED interlighting during summer. Nevertheless, different glazing and supplementary intracanopy LED lighting significantly affected yield, quality, and nutritional characteristics. Plant height, yield, DM, TSS, fructose, glucose, antioxidant capacity (DPPH, TEAC), TPC, and calcium, phosphorus, and manganese content were significantly lower in the double-glazed greenhouse than in the single-glazed greenhouse. The results for the aroma compounds, in contrast, were not consistent. The lower light transmission can explain the lower fruit quality in the double-glazed greenhouse system. Though it can be seen that the additional LED interlighting could reduce the negative effect of the double glazing, the effect of light will probably be even more decisive in the off season. We found no strong effect of additional LED interlighting on the parameters studied when there was already sufficient light available for the plants. The use of a double-glazed greenhouse during the in season can reduce some quality parameters and may only be preferable during the off season with supplementary LED lighting. Further research needs to be conducted to evaluate the positive and negative impacts of double-glazed greenhouse systems (low-energy greenhouses), especially for year-round production.

Supplementary Materials: The following are available online at https:/ / www.mdpi.com/article / 10.3390/agronomy11061203/s1, Figure S1: Mean daily values in the five cultivation systems of (A) temperature $\left[{ }^{\circ} \mathrm{C}\right],(\mathrm{B})$ relative humidity $[\%]$, and $(\mathrm{C})$ vapor pressure deficit $(\mathrm{VPD})[\mathrm{kPa}]$ over the entire period of fruit growth; Table S1: Mean values of yield parameters \pm standard deviation in different cultivation systems of five breeding lines and Lyterno $\mathrm{F}_{1}$; Table S2: Soil analyses in the low-input cultivation system (CS 5) before and after the experimental setup; Table S3: Mean values \pm standard deviation of 18 aroma compounds in different cultivation systems of five breeding lines and Lyterno $\mathrm{F}_{1}$; Table S4: Mean values in percent \pm standard deviation of sensory panel results in the cultivation systems CS1 and CS2 of five breeding lines and Lyterno $\mathrm{F}_{1}$; Table S5: Mean values \pm standard deviation of 38 metabolites detected in two breeding lines $(2,3)$ and Lyterno $F_{1}(6)$, and the fold change (FC) from cultivation system 4 (double-glazed greenhouse without LED) compared to cultivation system 2 (single-glazed greenhouse without LED) are shown. Further, mean values \pm standard deviation are shown for comparison of the 38 metabolites in the two breeding lines and Lyterno $\mathrm{F}_{1}$. 
Author Contributions: Conceptualization, L.K., H.K., M.N., J.H., A.U. and E.P.; methodology, L.K., H.K. and J.H.; formal analysis, L.K. and H.K.; investigation, L.K., H.K. and J.H.; resources, A.U. and E.P.; writing—original draft preparation, L.K. and H.K.; writing—review and editing, L.K., H.K., M.N., J.H., A.U. and E.P.; visualization, L.K.; supervision, M.N., A.U. and E.P. All authors have read and agreed to the published version of the manuscript.

Funding: This research was funded by the Ministry for Science and Culture of Lower Saxony, grant number VWZN3255.

Institutional Review Board Statement: The study was approved by Ethics Committee, University of Goettingen, P.O. Box 37 44, 37027 Goettingen, Chair: Prof. Dr. Hans Michael Heinig, (Date of approval was 26 July 2009).

Informed Consent Statement: Informed consent was obtained from all subjects involved in the study.

Data Availability Statement: Data from measurements are available upon request from the corresponding author.

Acknowledgments: We thank the technicians of the Division Quality of Plant Products (Arne Gull, Gunda Jansen, and Evelyn Krüger) for their technical assistance. We also thank Max Rehberg and Moritz Halekotte from Culinaris for their support for selection of the breeding lines, and Bernd Horneburg for his support in designing and carrying out the experiments in the organic cultivation system. Finally, we thank the Ministry for Science and Culture of Lower Saxony for their financial support of the PETRA ${ }^{q+n}$-project. We acknowledge support by the Open Access Publication Funds of the Goettingen University.

Conflicts of Interest: The authors declare no conflict of interest.

\section{References}

1. FAOSTAT. Available online: http://www.fao.org/faostat/en/\#data/QC (accessed on 30 March 2021).

2. Martínez-Valverde, I.; Periago, M.J.; Provan, G.; Chesson, A. Phenolic compounds, lycopene and antioxidant activity in commercial varieties of tomato (Lycopersicum esculentum). J. Sci. Food Agric. 2002, 82, 323-330. [CrossRef]

3. Pinela, J.; Barros, L.; Carvalho, A.M.; Ferreira, I.C.F.R. Nutritional composition and antioxidant activity of four tomato (Lycopersicon esculentum L.) farmer' varieties in Northeastern Portugal Homegardens. Food Chem. Toxicol. 2012, 50, 829-834. [CrossRef]

4. Tieman, D.; Zhu, G.; Resende, M.F.; Lin, T.; Nguyen, C.; Bies, D.; Rambla, J.L.; Beltran, K.S.O.; Taylor, M.; Zhang, B.; et al. A chemical genetic roadmap to improved tomato flavor. Science 2017, 355, 391-394. [CrossRef]

5. Tikunov, Y.M.; Roohanitaziani, R.; Meijer-Dekens, F.; Molthoff, J.; Paulo, J.; Finkers, R.; Capel, I.; Carvajal Moreno, F.; Maliepaard, C.; Nijenhuis-de Vries, M.; et al. The genetic and functional analysis of flavor in commercial tomato: The FLORAL4 gene underlies a QTL for floral aroma volatiles in tomato fruit. Plant J. 2020, 103, 1189-1204. [CrossRef]

6. Grandillo, S.; Cammareri, M. Molecular mapping of quantitative trait loci in tomato. In The Tomato Genome, Compendium of Plant Genomes; Causse, M., Giovannoni, J., Bouzayen, M., Zouine, M., Eds.; Springer: Berlin/Heidelberg, Germany, 2016 ; pp. 39-73. ISBN 978-3-662-53387-1.

7. Schouten, H.J.; Tikunov, Y.; Verkerke, W.; Finkers, R.; Bovy, A.; Bai, Y.; Visser, R.G.F. Breeding has increased the diversity of cultivated tomato in the Netherlands. Front. Plant Sci. 2019, 10. [CrossRef] [PubMed]

8. Gruda, N. Impact of environmental factors on product quality of greenhouse vegetables for fresh consumption. CRC Crit. Rev. Plant Sci. 2005, 24, 227-247. [CrossRef]

9. Shamshiri, R.R.; Jones, J.W.; Thorp, K.R.; Ahmad, D.; Man, H.C.; Taheri, S. Review of optimum temperature, humidity, and vapour pressure deficit for microclimate evaluation and control in greenhouse cultivation of tomato: A review. Int. Agrophys. 2018, 32, 287-302. [CrossRef]

10. Dzakovich, M.P.; Gómez, C.; Mitchell, C.A. Tomatoes grown with light-emitting diodes or high-pressure sodium supplemental lights have similar fruit-quality attributes. HortScience 2015, 50, 1498-1502. [CrossRef]

11. Gómez, C.; Morrow, R.C.; Bourget, C.M.; Massa, G.D.; Mitchell, C.A. Comparison of intracanopy light-emitting diode towers and overhead high-pressure sodium lamps for supplemental lighting of greenhouse-grown tomatoes. HortTechnology 2013, 23, 93-98. [CrossRef]

12. Morrow, R.C. LED lighting in horticulture. HortScience 2008, 43, 1947-1950. [CrossRef]

13. Borguini, R.G.; Ferraz Da Silva Torres, E.A. Tomatoes and tomato products as dietary sources of antioxidants. Food Rev. Int. 2009, 25, 313-325. [CrossRef]

14. Max, J.F.J.; Schurr, U.; Tantau, H.-J.; Mutwiwa, U.N.; Hofmann, T.; Ulbrich, A. Greenhouse cover technology. In Horticultural Reviews; Janick, J., Ed.; John Wiley \& Sons, Inc.: Hoboken, NJ, USA, 2012; pp. 259-396. ISBN 978-1-118-35187-1.

15. Tantau, H.-J.; Meyer, J.; Schmidt, U.; Bessler, B. Low energy greenhouse-A system approach. Acta Hortic. 2011, 75-84. [CrossRef] 
16. Wilms, D.; Römer, H.-P.; Rehrmann, P.; Bettin, A. Prüfung von wärmeschutzglas als bedachungsmaterial für die zierpflanzenproduktion. In Niedrigenergiegewächshäuser. Ergebnisse des ZINEG-Verbundprojektes; Kuratorium für Technik und Bauwesen in der Landwirtschaft e. V. (KTBL), Ed.; KTBL-Schrift: Darmstadt, Germany, 2015; ISBN 978-3-945088-14-2.

17. De Kreij, C.; Voogt, W.; Baas, R. Nutrient Solutions and Water Quality for Soilless Cultures; Applied Plant Research, Division Glasshouse: Naaldwijk, The Netherlands, 2003.

18. Kanski, L.; Naumann, M.; Pawelzik, E. Flavor-related quality attributes of ripe tomatoes are not significantly affected under two common household conditions. Front. Plant Sci. 2020, 11. [CrossRef] [PubMed]

19. Zhang, J.; Zhao, J.; Xu, Y.; Liang, J.; Chang, P.; Yan, F.; Li, M.; Liang, Y.; Zou, Z. Genome-wide association mapping for tomato volatiles positively contributing to tomato flavor. Front. Plant Sci. 2015, 6. [CrossRef] [PubMed]

20. DIN EN ISO 8586:2014-05, Sensorische Analyse_-Allgemeiner Leitfaden für die Auswahl, Schulung und Überprüfung Ausgewählter Prüfer und Sensoriker(ISO_8586:2012); Deutsche Fassung EN_ISO_8586:2014; Beuth Verlag GmbH: Berlin, Germany, 2014.

21. DIN EN ISO 8589:2014-10, Sensorische Analyse_- Allgemeiner Leitfaden für die Gestaltung von Prüfräumen (ISO_8589:2007_+ Amd_1:2014); Deutsche Fassung EN_ISO_8589:2010_+ A1:2014; Beuth Verlag GmbH: Berlin, Germany, 2010.

22. Mitchell, C.A.; Dzakovich, M.P.; Gomez, C.; Lopez, R.; Burr, J.F.; Hernández, R.; Kubota, C.; Currey, C.J.; Meng, Q.; Runkle, E.S.; et al. Light-emitting diodes in horticulture. In Horticultural Reviews; Janick, J., Ed.; John Wiley \& Sons, Inc.: Hoboken, NJ, USA, 2015; Volume 43, pp. 1-88. ISBN 978-1-119-10778-1.

23. Paucek, I.; Appolloni, E.; Pennisi, G.; Quaini, S.; Gianquinto, G.; Orsini, F. LED lighting systems for horticulture: Business growth and global distribution. Sustainability 2020, 12, 7516. [CrossRef]

24. Tewolde, F.T.; Lu, N.; Shiina, K.; Maruo, T.; Takagaki, M.; Kozai, T.; Yamori, W. Nighttime supplemental LED inter-lighting improves growth and yield of single-truss tomatoes by enhancing photosynthesis in both winter and summer. Front. Plant Sci. 2016, 7. [CrossRef] [PubMed]

25. Papadakis, G.; Briassoulis, D.; Scarascia Mugnozza, G.; Vox, G.; Feuilloley, P.; Stoffers, J.A. Review paper (SE-Structures and environment). J. Agric. Eng. Res. 2000, 77, 7-38. [CrossRef]

26. Bradfield, E.G.; Guttridge, C.G. Effects of night-time humidity and nutrient solution concentration on the calcium content of tomato fruit. Sci. Hortic. 1984, 22, 207-217. [CrossRef]

27. Rosales, M.A.; Cervilla, L.M.; Sánchez-Rodríguez, E.; del Mar Rubio-Wilhelmi, M.; Blasco, B.; Ríos, J.J.; Soriano, T.; Castilla, N.; Romero, L.; Ruiz, J.M. The effect of environmental conditions on nutritional quality of cherry tomato fruits: Evaluation of two experimental mediterranean greenhouses. J. Sci. Food Agric. 2011, 91, 152-162. [CrossRef] [PubMed]

28. Beckles, D.M. Factors affecting the postharvest soluble solids and sugar content of tomato (Solanum lycopersicum L.) fruit. Postharvest Biol. Technol. 2012, 63, 129-140. [CrossRef]

29. Klee, H.J.; Tieman, D.M. The genetics of fruit flavour preferences. Nat. Rev. Genet. 2018, 19, 347-356. [CrossRef] [PubMed]

30. Baldwin, E.A.; Goodner, K.; Plotto, A. Interaction of volatiles, sugars, and acids on perception of tomato aroma and flavor descriptors. J. Food Sci. 2008, 73, S294-S307. [CrossRef] [PubMed]

31. Vogel, J.T.; Tieman, D.M.; Sims, C.A.; Odabasi, A.Z.; Clark, D.G.; Klee, H.J. Carotenoid content impacts flavor acceptability in tomato (Solanum lycopersicum). J. Sci. Food Agric. 2010, 90, 2233-2240. [CrossRef] [PubMed]

32. Cebolla-Cornejo, J.; Roselló, S.; Valcárcel, M.; Serrano, E.; Beltrán, J.; Nuez, F. Evaluation of genotype and environment effects on taste and aroma flavor components of Spanish fresh tomato varieties. J. Agric. Food Chem. 2011, 59, 2440-2450. [CrossRef] [PubMed]

33. Lee, J.H.J.; Jayaprakasha, G.K.; Avila, C.A.; Crosby, K.M.; Patil, B.S. Metabolomic studies of volatiles from tomatoes grown in net-house and open-field conditions. Food Chem. 2019, 275, 282-291. [CrossRef]

34. Gautier, H.; Diakou-Verdin, V.; Bénard, C.; Reich, M.; Buret, M.; Bourgaud, F.; Poëssel, J.L.; Caris-Veyrat, C.; Génard, M. How does tomato quality (sugar, acid, and nutritional quality) vary with ripening stage, temperature, and irradiance? J. Agric. Food Chem. 2008, 56, 1241-1250. [CrossRef] [PubMed]

35. Yilmaz, E. The chemistry of fresh tomato flavor. Turk. J. Agric. For. 2001, 25, 149-155.

36. Costa, F.; de Lurdes Baeta, M.; Saraiva, D.; Verissimo, M.T.; Ramos, F. Evolution of mineral contents in tomato fruits during the ripening process after harvest. Food Anal. Methods 2011, 4, 410-415. [CrossRef]

37. Hernández Suárez, M.; Rodríguez Rodríguez, E.M.; Díaz Romero, C. Mineral and trace element concentrations in cultivars of tomatoes. Food Chem. 2007, 104, 489-499. [CrossRef]

38. Dzakovich, M.P.; Ferruzzi, M.G.; Mitchell, C.A. Manipulating sensory and phytochemical profiles of greenhouse tomatoes using environmentally relevant doses of ultraviolet radiation. J. Agric. Food Chem. 2016, 64, 6801-6808. [CrossRef]

39. Dzakovich, M.P.; Gómez, C.; Ferruzzi, M.G.; Mitchell, C.A. Chemical and sensory properties of greenhouse tomatoes remain unchanged in response to red, blue, and far red supplemental light from light-emitting diodes. HortScience 2017, 52, 1734-1741. [CrossRef]

40. Kowalczyk, K.; Gajc-Wolska, J.; Metera, A.; Mazur, K.; Radzanowska, J.; Szatkowski, M. Effect of supplementary lighting on the quality of tomato fruit (Solanum lycopersicum L.) in autumn-winter cultivation. Acta Hortic. 2012, 395-401. [CrossRef]

41. Snowden, C.J.; Thomas, B.; Baxter, C.J.; Smith, J.A.C.; Sweetlove, L.J. A tonoplast glu/asp/gaba exchanger that affects tomato fruit amino acid composition. Plant J. 2015, 81, 651-660. [CrossRef] [PubMed] 
42. Zanor, M.I.; Rambla, J.-L.; Chaib, J.; Steppa, A.; Medina, A.; Granell, A.; Fernie, A.R.; Causse, M. Metabolic characterization of loci affecting sensory attributes in tomato allows an assessment of the influence of the levels of primary metabolites and volatile organic contents. J. Exp. Bot. 2009, 60, 2139-2154. [CrossRef] [PubMed]

43. Biais, B.; Bénard, C.; Beauvoit, B.; Colombié, S.; Prodhomme, D.; Ménard, G.; Bernillon, S.; Gehl, B.; Gautier, H.; Ballias, P.; et al. Remarkable reproducibility of enzyme activity profiles in tomato fruits grown under contrasting environments provides a roadmap for studies of fruit metabolism. Plant Physiol. 2014, 164, 1204-1221. [CrossRef] [PubMed] 